\title{
Preparation of single-cell suspension from mouse breast cancer focusing on preservation of original cell state information and cell type composition
}

\author{
Abaffy Pavel $^{1}$, Lettlova Sandra ${ }^{1}$, Truksa Jaroslav $^{1}$, Kubista Mikael ${ }^{1,2}$, Sindelka Radek $^{1,3,{ }^{*}}$ \\ ${ }^{1}$ Laboratory of gene expression, Institute of Biotechnology of the Czech Academy of Sciences - BIOCEV, Prumyslova \\ 595, Vestec, 252 50, Czech Republic \\ ${ }^{2}$ TATAA Biocenter, Odinsgatan 28, Göteborg, 411 03, Sweden \\ ${ }^{3}$ Lead Contact \\ ${ }^{*}$ Correspondence: radek.sindelka@ibt.cas.cz
}

\section{SUMMARY}

Single-cell analysis of gene expression has become a very popular method during the last decade. Unfortunately, appropriate standardization and workflow optimization remain elusive. The first step of the single cell analysis requires that the solid tissue be disassociated into a suspension of individual cells. However, during this step several technical bias can arise which can later result in the misinterpretation of the data. The goal of this study was to identify and quantify the effect of these technical factors on the quality of the single-cell suspension and the subsequent interpretation of the produced expression data. We tested the effects of various enzymes used for dissociation, several centrifugation forces, dissociation temperatures and the addition of Actinomycin D, a gene expression inhibitor. RT-qPCR was used to assess the effect from each parameter alteration, while a single-cell RNA sequencing experiment was used to confirm the optimized factors. Our concluding results provide a complete protocol for the tissue dissociation of mouse mammary tumour from 4T1 cells that preserves the original cell state and is suitable for any single-cell RNA sequencing analysis. Furthermore, our workflow may serve as a guide for the optimization of the dissociation procedure of any other tissue of interest, which would ultimately improve the reproducibility of the reported data.

\section{KEYWORDS}

Single-cell, RNA Sequencing, dissociation, tumour 


\section{INTRODUCTION}

It has been more than 10 years since Tang et al. (2009) published the first paper on the analysis of the whole transcriptome from single cells (single-cell RNA-Seq, scRNA-Seq). Since then, scientists have produced optimized protocols for the preparation of sequencing libraries from individual cells. Such protocols have allowed for many different discoveries from the cell such as gene expression, chromatin modifications, copy number variation, and other "omics" (such as proteomics) (Guo et al., 2017; Cheung et al., 2018; Hou et al., 2016; Andor et al., 2018). However, the first step utilized by all these protocols is the preparation of the single-cell suspension, also known as tissue dissociation. Unfortunately, cells react to the stress induced by the disassociation process and this often leads to an artificial induction of gene expression. The level of this artificial induction is dependent on the particular dissociation protocol and sample type (van den Brink et al., 2017; Adam, Potter and Potter, 2017; Wu et al., 2017) and is confounded within the original expression pattern which can lead to biological misinterpretations (van den Brink et al., 2017). Recently, the problem of dissociation associated induced expression was discussed and suggested as a problematic factor during single cell analyses (van den Brink et al., 2017). During the dissociation process, certain genes within the cells have a sudden burst in expression. These genes usually consist of the stress induced or immediate early genes (IEGs). Interestingly, this set of genes is conserved in higher eukaryotes and has been observed after injury in mouse (Grose et al., 2002), fish (Ishida et al., 2010) and also during embryonic wound healing at the gastrula and tailbud stages in Xenopus embryos (Ding et al., 2017; Abaffy et al., in press). Usually the peak expression of these genes appears between 30 and 60 minutes after treatment/injury. Additionally, upregulation of many IEGs has also been observed in post-mortem tissue derived from mouse and fish (Pozhitkov et al., 2017). This particular group of genes consists of members within the AP1 pathway and heat-shock proteins.

One of the suggested solution for this issue is to filter out cells expressing IEGs during data analysis (van den Brink et al., 2017). Unfortunately, this approach would also eliminate cells that were naturally responding to other innate biological stress situations. Another solution is to modify the dissociation protocol to prevent/reduce induction of the IEGs expression. The first approach from this solution would be to perform dissociation and all subsequent steps at a lower temperature, which would significantly reduce the metabolic processes within the cells (Adam, Potter and Potter, 2017). However, a drawback of this approach is that the lower temperature would also decreases the efficacy of the dissociation enzymes. This would result in an incomplete dissociation of the tissue and the subsequent loss of some cell populations. The second approach is to use a transcription inhibitor to reduce IEGs expression during dissociation. Addition of Actinomycin D (ActD) has alreadu been successfully used during dissociation of neuronal tissue into singlecell suspension, where it was found to greatly reduced IEGs expression (Wu et al., 2017). However, the routine usage of inhibitors is limited because of their concentration and cell type dependent toxicity. The third approach is to use fixed tissue (Machado et al., 2017), which would render biological processes inactive. However, this approach requires the fixation of the tissue in paraformaldehyde (PFA) which leads to the cross-linking of proteins with RNA and can lead to a worse quality of the RNA. Interestingly, Machado et al. (2017) found no alteration in mRNA yield, quality, and composition when using fixed samples. However, they only analysed the effect of PFA fixation at the bulk level.

The last approach is single-nucleus RNA sequencing (snRNA-Seq) using flash-frozen tissue (Habib et al., 2016; Habib et al., 2017; Krishnaswami, S. R. et al., 2016; Lacar, B. et al., 2016). We et al. (2019) observed that there was no artificial transcriptional stress response when using snRNA-Seq. However, an important question remains on whether the nuclear RNA content represents well the whole cell transcriptome. Comparative studies (Grindberg, R. V. et al., 2013; Gao, R. et al., 2017; Habib et al., 2017) have shown an overall high correlation between scRNA-Seq and snRNA-Seq. However, small variations between the two methods have been observed in the content of poly-adenlyated ncRNAs (Krishnaswami, S. R. et al., 2016), enrichment of IncRNAs (Gao, R. et al., 2017) and abundance of intronic sequences (Grindberg, R. V. et al., 2013; Gao, R. et al., 2017; Habib et al., 2017). These biases must be removed during data analysis. 


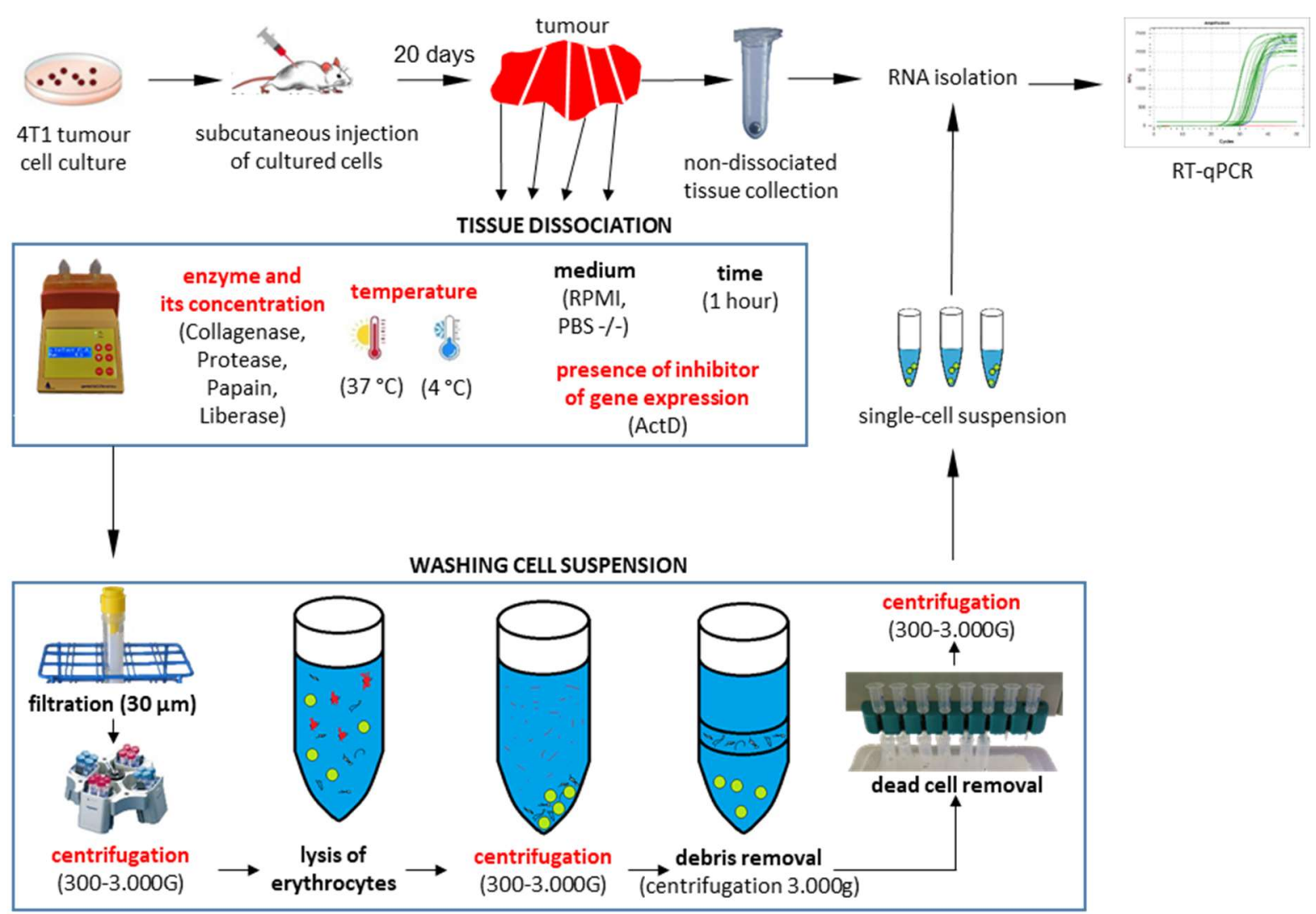

Figure 1: Scheme of the process of preparation of the single-cell suspension from the tumour tissue. Factors, which were optimized, are marked by red colour.

An additional obstacle during tissue dissociation is the reduction or even loss of cell subpopulations. Contrarily to the previously described problems, the impact of this loss on the interpretation of the final data is not sufficiently discussed in the literature. Recent studies have already touched on some of these issues that may arise during tissue dissociation (Potter and Potter, 2019). These studies have warned that scientists should not expect an accurate representation of the cell-types from data derived from the scRNA-Seq. A general suggestion to improve the quality of the single-cell suspension is through protocol optimization. However this is necessary for each type of tissue as there is no "one correct solution" for all types (Vieira Braga and Miragaia, 2019; Potter and Potter, 2019).

Tumour heterogeneity has been described many times in the literature (Winterhoff et al., 2017; Tirosh et al., 2016; Puram et al., 2017; Patel et al., 2014; Hou et al., 2016) and large-scale single-cell analyses performed from tumour biopsies or whole tumour tissues represent a great challenge. In addition, the complexity of a single tumour cell analysis comes from combined regulation by both intertumoural and extratumoural factors (Lawson et al., 2018). The critical aspect of these analyses is preservation of the original intact tumour signatures in terms of its cell populations, types and states (Lawson et al., 2018). Our goal here is to demonstrate questions and solutions during protocol optimization for single-cell suspension preparation with the main challenge of reduction of IEGs expression. Our work discusses the effect of the different protocol steps and their impact on the results interpretation.

\section{RESULTS}

The process of preparing the single-cell suspension from the fresh solid tissue includes several modifiable steps (Figure 1). We utilized a 10x Genomics protocol as a gold standard for single-cell suspension preparation (10x Genomics, 2018; 10x Genomics, 2017). The protocol included: lysis of the erythrocytes to prevent issues with counting of the viable cells when using an automatic cell counter; removal of debris 


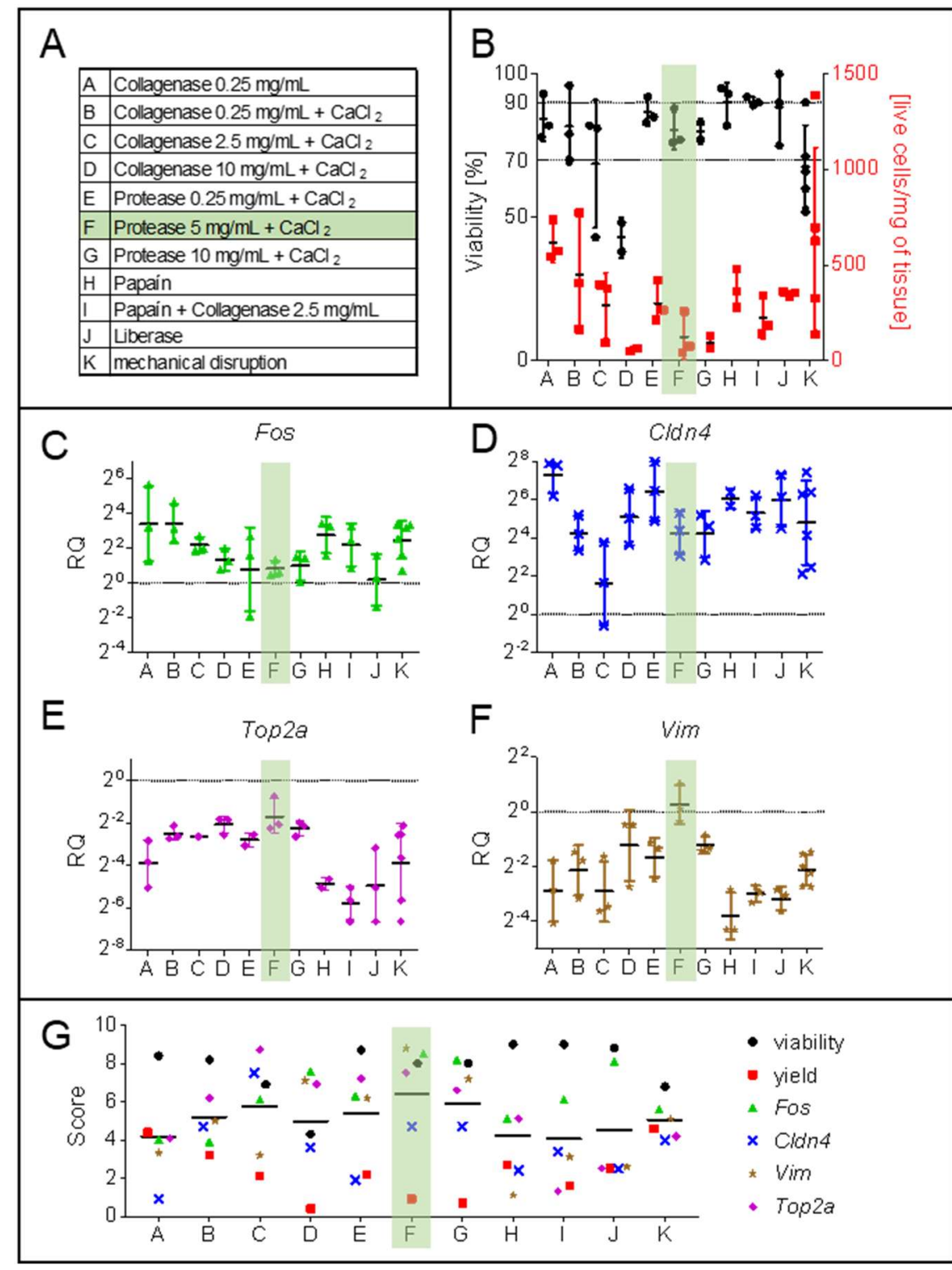

Figure 2: The effect of various enzymes and their combination on dissociation of the tumour tissue.

(A) List of compared conditions. The condition found as optimal is marked in green. (B) Effect of using different enzymes during tumour dissociation ( $4{ }^{\circ} \mathrm{C}$ for 1 hour) on cellular viability (black) and yield (red). The recommended viability at least $90 \%$ and minimal viability $70 \%$ are marked in the graph. (mean \pm SD) (C-F) The effect of different enzymes and their concentrations on relative gene expression of marker genes after dissociation normalized to non-dissociated tissue piece. The black line represents the expression in non-dissociated tumour tissue. (geometric mean with geometric SD) (C) Fos - a member of IEGs, (D) Cldn4 - a marker of tumour endothelial stem cells, (E) Top2a - a marker of proliferating cells, (F) Vim a marker of tumour epithelial cells. (G) Score (from worst 0 to best 10) were calculated for each condition and parameter. Mean of the scores is shown.

See also Figure $\mathbf{S 1 .}$

which would otherwise contribute to a high RNA background; and removal of dead cells which would reduce the cell viability. We optimized this protocol by using a low dissociation temperature $\left(4^{\circ} \mathrm{C}\right)$ as well as with the addition of ActD during dissociation, so as to minimize the dissociation-associated stress response. We tested also different enzymes, their concentrations and the effect of centrifugation on cell suspension quality.

\section{Selection of dissociation enzyme}

In the first step of the protocol optimization, we tested various dissociation enzymes using the recommended parameters. We also altered the following factors that may also contribute to the artificial gene expression via stimulation/degradation: i) low dissociation temperature $\left(4^{\circ} \mathrm{C}\right)$; ii) presence of transcription inhibitor ActD; iii) centrifugation at $300 \mathrm{~g}$. The specific enzymes and their concentrations were selected based on available commercial and scientific protocols (in total ten different conditions, (Figure 2A): Collagenase, which was used in previous experiments during dissociation at $37^{\circ} \mathrm{C}$; Protease, which was used by Adam, et al. (2017); Papain, which is often used for dissociation of embryonic tissues at low temperature; Liberase $^{\mathrm{TM}}$, a mixture of enzymes with expected higher activity in comparison to Collagenase. The $\mathrm{Ca}^{2+}$ ions were added into medium, because it is important for activation of Collagenase. Negative control was 
performed as a mechanical disruption in the absence of any enzyme.

The first tested parameter was cell viability. A high cell viability is a critical parameter for all droplet based scRNA-Seq methods, because dying cells release RNA into solution and this can result in unspecific RNA background in all cells and decrease the sensitivity to identify different cell types. The manufacturers of single-cell droplet instruments have declared that an optimal cell viability should be more than $90-95 \%$ (Illumina and Bio-Rad, 2017). Some manuals have suggested as low as at least $70 \%$ viable cells (10x Genomics, 2018). In our experiment, none of the dissociation conditions resulted in cell viability higher than $90 \%$ (Figure 2B). However, only two conditions showed an average viability lower than $70 \%$ : Collagenase at the highest concentration $(10 \mathrm{mg} / \mathrm{ml})$ and mechanical disruption.

The second studied parameter was the cell yield after dissociation. The amount of the tissue used can also be a limiting parameter, especially for smaller and younger tumours. The low number of live cells obtained during dissociation indicates an ineffective dissociation or a high proportion of the disrupted cells. Surprisingly, the highest yield was achieved after mechanical disruption and dissociation using the Collagenase $(0.25 \mathrm{mg} / \mathrm{ml})$ without the addition of $\mathrm{CaCl}_{2}$ (Figure 2B). The higher enzymatic activity (after addition of $\mathrm{CaCl}_{2}$ or at higher concentrations of the enzymes) probably led to the disruption of cell membranes, which resulted in lower dissociation yields.

Any changes of the gene expression during sample preparation are unwanted. The artificial induction of gene expression and specific cell type dissociation were measured using RT-qPCR analysis of IEGs and mammary tumour cell types markers (Figure 2C-F, Figure S1). Gene expression was compared between the single-cell suspension and the non-dissociated tissue sample prepared in parallel (Figure 1). Activation of IEGs was determined using expression of Fos, as a prime example of IEG (Figure $\mathbf{2 C}$ ). Expression most closest to the non-dissociated tissue was obtained by using Liberase, Protease (any concentration) and Collagenase $(10 \mathrm{mg} / \mathrm{ml})$. The remaining conditions led to an increase in Fos expression more than 5 fold relative to the non-dissociated tumour. The marker of cells, which easily dissociate from tumour tissue into suspension (Cldn4+; tumour endothelial stem cells) was enriched in all studied conditions (Figure 2D). On the other hand, the expression of a marker of cells which hardly dissociates from tumour tissue into suspension (Vim; mammary tumour epithelial cells) or a marker of proliferating cells (Top2a) was decreased (Figure 2E,F). The best condition that exhibited comparable expression relative to the non-dissociated tissue were observed using Protease and Collagenase with the addition of $\mathrm{CaCl}_{2}$ (Figure 2E). Similarly, the smallest relative expressional changes of $\mathrm{Vim}$ (Figure 2F) were determined in Collagenase $(10 \mathrm{mg} / \mathrm{ml})$ and Protease treatments (any concentration).

A scoring system from 0 (worst) to 10 (best) was developed and applied to combine all studied parameters (details in Method section). The lowest score $(6.4 \pm 3.1)$, which reflected the most efficient and reliable dissociation parameters, was obtained for Protease from Bacillus licheniformis at a concentration of $5 \mathrm{mg} / \mathrm{ml}$ (Figure 2G). The remaining conditions showed scores ranging from 4.1 to 5.9.

\section{The effect of the centrifugal force on the quality of cell suspension}

The decrease in the gene expression of the cellular markers such as Vim and Top2a (Figure 2C-F), suggested a loss of these particular cell subpopulations in the final suspension. Previous studies have recommended the use of a higher centrifugal force for the collection of smaller cells. We tested centrifugation forces ranging from 300 to $3000 \mathrm{~g}$ (Figure 1) in combination with Protease $(5 \mathrm{mg} / \mathrm{ml})$ for dissociation $\left(4^{\circ} \mathrm{C}, \mathrm{ActD}\right)$ and analysed the same set of parameters as in Figure 2. We found that cell viability is negatively affected by an increased centrifugal force. (Figure 3B). On the other hand, the yield of cell collection is proportional to centrifugal force (Figure $3 \mathrm{C}$ ). No effect on the expression of Fos was observed when the centrifugal force was increased (Figure 3D). Similarly, no changes were detected in the expression of the proliferation marker (Top2a) or mammary tumour epithelial cell marker (Vim) (Figure 3F,G). The positive effect of an increased centrifugation force was however observed on the expression of Cldn4 (marker of tumour endothelial stem cells). The higher centrifugal force led to lower enrichment of the Cldn4+ cells (Figure 3E). 


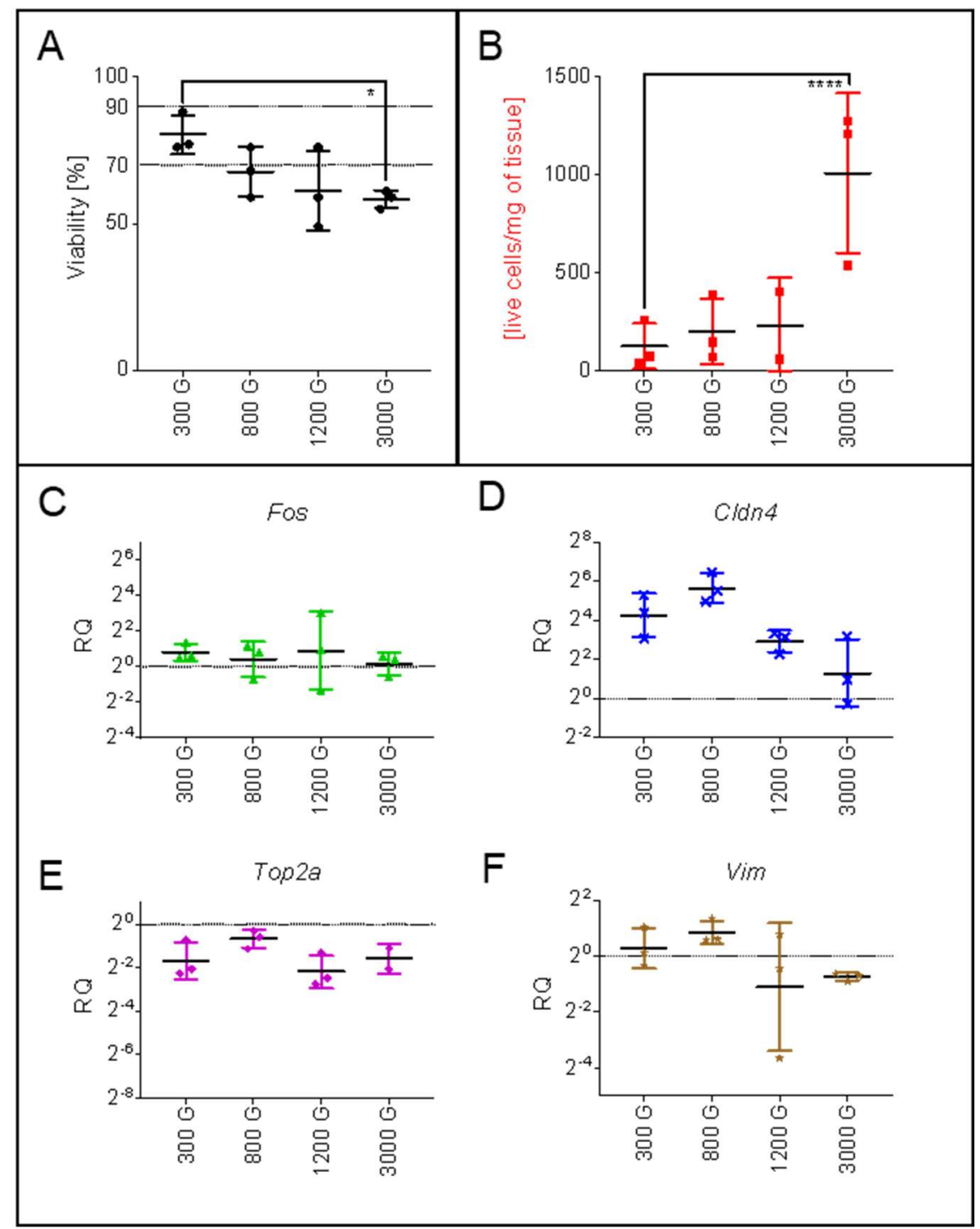

Figure 3: The effect of centrifugation force after tumour tissue dissociation on cellular viability and gene expression.

(A) Cell viability after spinning them by different centrifugation force are shown in black. The recommended viability at least $90 \%$ and minimal viability $70 \%$ are marked in the graph. (mean \pm SD) (B) Yields of cells after usage of various centrifugation forces are shown in red (mean \pm SD). (C-F) The effect of centrifugation forces studied by relative expression of marker genes after dissociation normalized to nondissociated tissue pieces. The black line represents the expression in non-dissociated tumour tissue. (geometric mean with geometric SD) (C) Fos - a member of IEGs, (D) Cldn4 - a marker of tumour endothelial stem cells, (E) Top2a -a marker of proliferating cells, (F) Vim a marker of tumour epithelial cells.

Dunnett's multiple comparisons test, $* * * *-p<$ $.0001, *-p<.05$, n.s. $-p>.05$

See also Figure $\mathbf{S 2}$.

Even though the highest centrifugal force of $3000 \mathrm{~g}$ led to the highest yields and showed the best preservation of the cell composition, viability as a crucial parameter in single cell analysis was compromised. We found that centrifugation at $800 \mathrm{~g}$ resulted in an average viability of $70 \%$, which is the minimal required viability for further downstream analyses, while retaining appreciable cell yield and good composition of cell types.

\section{The effect of different temperature on the cell quality and expression of IEGs}

Previous studies (Adam, Potter and Potter, 2017; Wu et al., 2017) have focused only on the impact of the activation of IEGs expression during tissue dissociation. We compared the effect of different dissociation temperatures $\left(37^{\circ} \mathrm{C}\right.$ and $4{ }^{\circ} \mathrm{C}$ ) and the presence of the transcription inhibitor (ActD) on the studied parameters (viability, yield, changes in cell types proportion), in combination with Protease $(5 \mathrm{mg} / \mathrm{ml})$ for dissociation and $800 \mathrm{~g}$ for centrifugation. Conditions were compared to dissociation at $37^{\circ} \mathrm{C}$ in the absence of the inhibitor, because standard working temperature for the majority of the enzymes used for tissue dissociation is usually at $37^{\circ} \mathrm{C}$ or higher.

Cell viability in samples dissociated at $37^{\circ} \mathrm{C}$ in the absence of the inhibitor was $86 \pm 5 \%$ (Figure 4A). Although the treatment with ActD as well as the treatment at the lower dissociation temperature led to lower viability, the change was statistically insignificant relative to the control. However, we expected that the administration of ActD would lead to an increase in the number of dying cells (its toxic effect published by Cortes et al. (2016)), and subsequently to lower cell 


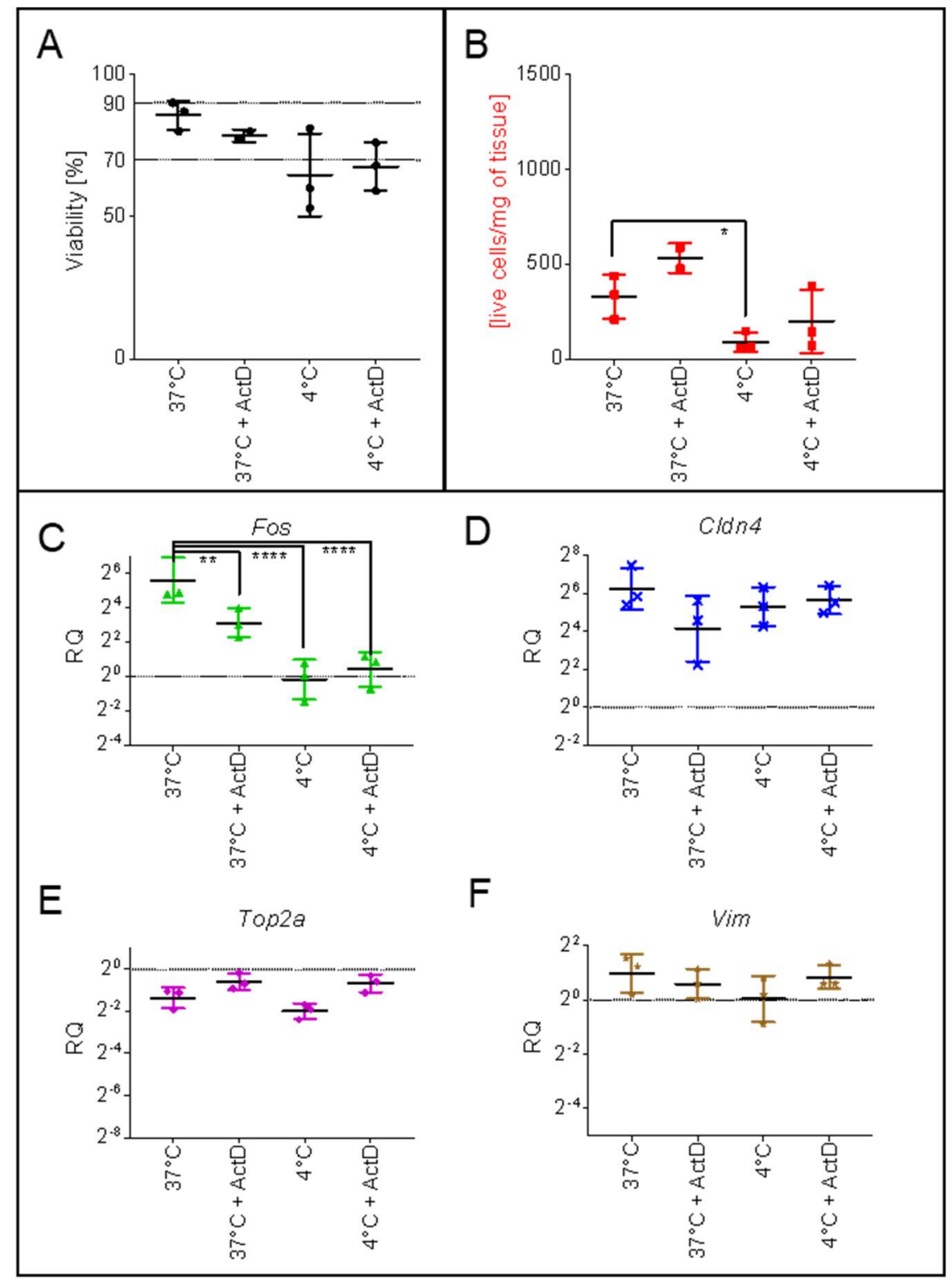

Figure 4: The effect of temperature oncell viability, yield and gene expression in dissociated tumour tissue.

(A) Cell viability at different temperature and in the presence or absence of ActD are shown in black. The recommended viability at least $90 \%$ and minimal viability $70 \%$ are marked in the graph. (mean \pm SD) (B) Yields of cells at different temperature and in the presence or absence of ActD are shown in red (mean $\pm S D$ ). (C-F) The effect of dissociation temperatures and presence of ActD studied by relative expression of marker genes after dissociation normalized to non-dissociated tissue piece. The black line represents the expression in non-dissociated tumour tissue. (geometric mean with geometric SD) (C) Fos - a member of IEGs, (D) Cldn4 - a marker of tumour endothelial stem cells, (E) Top $2 a$ - a marker of proliferating cells, (F) Vim a marker of tumour epithelial cells.

Dunnett's multiple comparisons test, $* * * *-p<$ $.0001, * *-p<.01, *-p<.05$, n.s. $-p>.05$

See also Figure $\mathbf{S 3}$.

yield. Surprisingly, the yield was comparable or even higher during dissociation at $37^{\circ} \mathrm{C}$ (Figure 4B). To explain this effect, we analysed changes in the number of the cells during incubation of the cell suspension at $37{ }^{\circ} \mathrm{C}$ in the presence or the absence of the ActD (Figure S3A). Incubation of the cells in the absence of the inhibitor led to a decreased cell number, but addition of the inhibitor stopped cells dying. The dissociation at $4{ }^{\circ} \mathrm{C}$ led to a decrease in the yield of the cells (Figure 4B). The observed difference in the yield between dissociation temperatures was greater after dissociation of the early stage tumour (10 days after injection) (Figure S3B).
Even though the dissociation at $4{ }^{\circ} \mathrm{C}$ resulted in a lower yield and lower cell viability, it more importantly resulted in an overall lower artificial induction of the IEGs. The fold change of Fos expression during dissociation at $37^{\circ} \mathrm{C}$ was $48^{*} \div 2.5$ times higher (Figure 4C) in comparison with non-dissociated tumour tissue and $8.5 * \div 1.8$ times higher when ActD was used. The dissociation at $4{ }^{\circ} \mathrm{C}$ showed almost no change of Fos expression during dissociation, and the additional effect of ActD was minimal. No statistically significant changes of other gene expression markers were observed (Figure 4D-F, Figure S3C-F). 


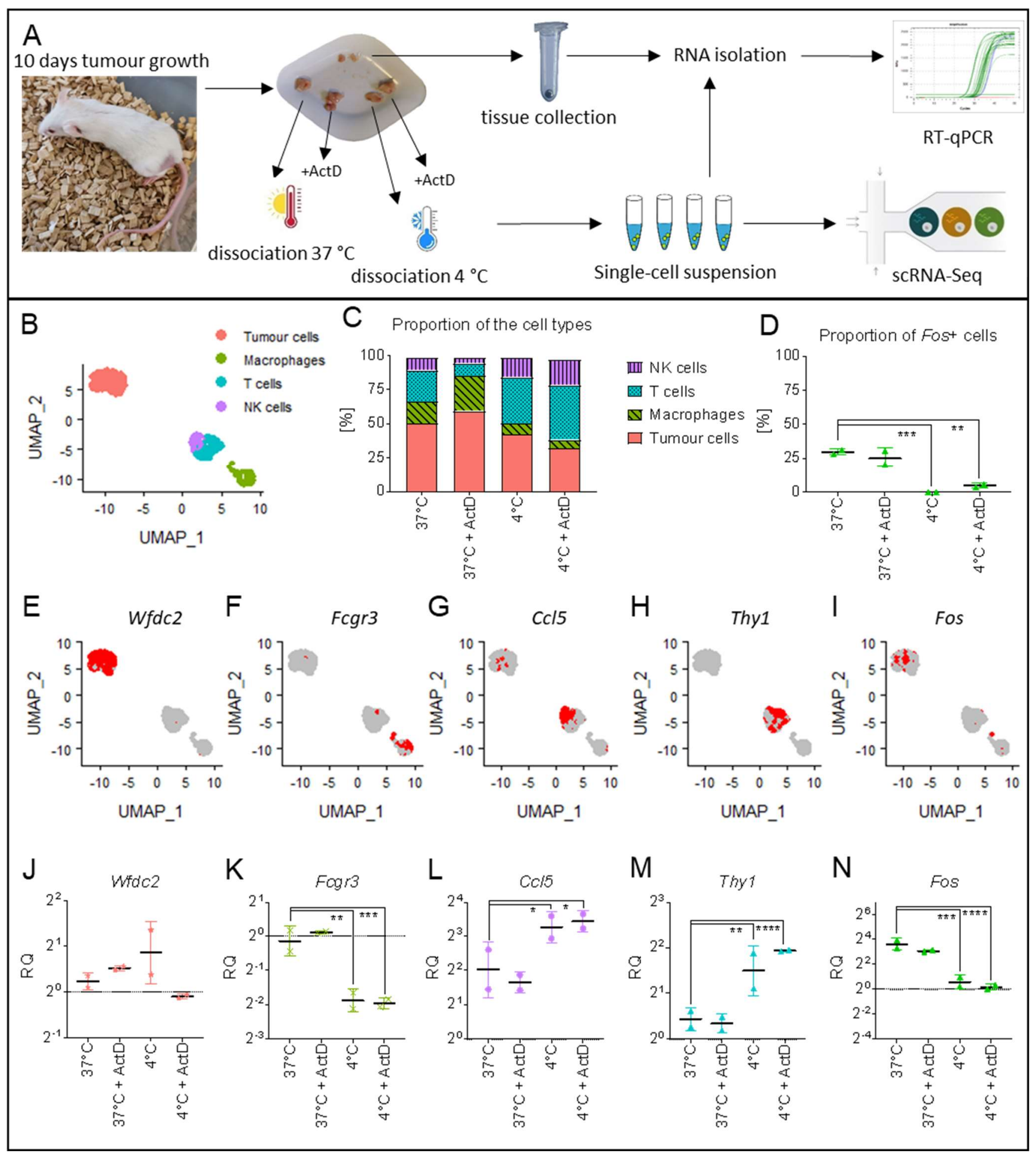

Figure 5: Comparison of scRNA and RT-qPCR for identification of population distribution in tumour tissue.

(A) Scheme of the comparison of scRNA-Seq and RT-qPCR experiments. (B-I) Results from scRNA-Seq. (B) UMAP plot of identified cell types. (C) Proportion of the cell types after each different dissociation condition relative to all cells. (D) Proportion of the Fos+ cells. (E-I) UMAP plot with marked individual cells positive for expression of different markers. (J-N) RT-qPCR analysis of relative expression of marker genes for cell population after dissociation of tumour compared with non-dissociated tissue. The black line represents the expression in non-dissociated tumour tissue. (geometric mean with geometric SD) (D,I) Wfdc2 -a tumour cells (E,J) Fcgr3 - Macrophages/monocytes (F,K) Ccl5 - NK cells (G,L) Thy 1 - T cells (H,M) Fos - one member of IEGs.

Dunnett's multiple comparisons test. ${ }^{* * *}-\mathrm{p}<.0001, * * *-p<.001, * *-p<.01, *-p<.05$, n.s. $-p>.05$ 
The effect of the different dissociation conditions on the interpretation of scRNA-Seq experiment

We performed single-cell RNA-Seq to study the effect of temperature and the transcriptional inhibitor ActD, on the representation of individual cellular populations within the tumour sample (Figure 5A). We collected tumour tissue after 10 days of the growth, dissociated it and compared scRNA-Seq data with analysis using RT-qPCR from the same samples (Figure 5A). ScRNASeq analysis contained 654 cells, which were divided into four main cellular types: Tumour cells, Macrophages, $T$ cells and Natural killer (NK) cells (Figure 5B).

ScRNA-Seq analysis of the cell type representation showed a higher proportion of the Tumour cells and Macrophages after dissociation at $37^{\circ} \mathrm{C}$ while a higher proportion of the NK and T cells after dissociation at $4{ }^{\circ} \mathrm{C}$ (Figure $5 \mathrm{C}$ ). To compare the scRNA-Seq results with data from the original non-dissociated tissue, we analysed the expression of cell markers of these populations using RT-qPCR. The distribution of the cell populations showed minimal or small differences in the expression of all four markers after dissociation at $37^{\circ} \mathrm{C}$, but higher differences in the expression of markers of the Macrophages, NK cells and T cells after dissociation at $4{ }^{\circ} \mathrm{C}$ (Figure 5J-M). The effect of the ActD on the population representation was minimal. The induction of IEGs expression was analysed as changes of the expression of Fos. The analysis revealed that $30 \%$ of examined cells were positive for the artificial induction of Fos gene expression when dissociated at $37^{\circ} \mathrm{C}$ compared to only $5 \%$ when dissociated at $4{ }^{\circ} \mathrm{C}$. (Figure 5D). Similar results were observed after RT-qPCR (Figure $\mathbf{5 N}$ ). Interestingly, the activation of Fos expression was specific mainly to tumour cells (Figure S4A,C) as $53 \%$ of tumour cells showed expression of Fos at $37^{\circ} \mathrm{C}$ dissociation (Figure S4B). Even though the dissociation at $37{ }^{\circ} \mathrm{C}$ led to better preservation of the cell composition, the crucial reduction of artificial gene expression remains the main benefit of lower dissociation temperature.

\section{DISCUSSION}

The ability to dissociate tissue into a suspension of individual cells, while preserving the cell composition and initial gene expression as the original tissue, is required for precise single cell analyses. Maintaining such consistency becomes exceptionally vital for the accurate description of the tissue microenvironment and heterogeneity as well as the identification of new cell types and the characterization of the cellular behaviour within complex biological tissues. The protocol for tissue dissociation is complex and each step positively or negatively affects the quality and interpretation of the experiment. In our study, we compared several factors such as the selection of the dissociation enzyme, dissociation temperature, presence of transcription inhibitor and centrifugal force on the tumour tissue dissociation and single-cell suspension quality.

In our experiment, we tested several enzymes and their concentrations, with the goal to identify the optimum dissociation parameters to transform mouse tumour tissue into single cell suspension while maintaining its quality, for use with droplet based single cell library preparation instrument such as Chromium (10x Genomics) or ddSEQ (Bio-Rad). We created a scoring system to compare not only the dissociation yield and viability, but also to test the expressional changes of specific cell type markers and IEGs. Using our scoring system, we found that overall the best choice for 4T1 tumour dissociation was the use of the Protease from Bacillus licheniformis. Previously this protease has been deemed as "Psychrophilic" or "cold active" (Adam, Potter and Potter, 2017; Joshi and Satyanarayana, 2013), even though Tokoyawa et al. (2010) described its maximal activity at $50^{\circ} \mathrm{C}$. A decrease in temperature led to a decrease in the protease activity: $20 \%$ of maximal activity at $37^{\circ} \mathrm{C}$, and only about $5 \%$ of maximal activity at $20^{\circ} \mathrm{C}$ (Toyokawa et al., 2010). The problem with low activity of the enzyme at the low temperature was solved by using a higher concentration, which resulted in a better score in more cases. Comparing the relation between the expressional changes and the concentration of enzymes, we concluded that at low temperature, effective tissue dissociation is less dependent on the enzyme type but rather on the concentration used.

During tissue dissociation obtaining both a high cell yield and cell viability are important, but often contradictory factors. Lower dissociation temperature is required for inactivation of IEGs, but leads to the reduction of the enzymatic activity. In contrast, too high enzyme concentration can lead to cell membrane 
degradation, decreasing cell viability. Cell disruption rate is probably cell type dependent. Therefore, it is possible that an uneven degradation can result in a decrease or even loss of specific cell subpopulations. The optimal combination of parameters depends on the particular experimental requirements (cell concentration, minimal required cell viability and quality of cell suspension) and on the type and size of the dissociated tissue. For example, the low dissociation temperature led to changes in the proportion of the immune cells in the tumour microenvironment (Figure $\mathbf{5 C}, \mathbf{J}-\mathbf{L}$ ). Such proportional changes caused by the dissociation protocol could led to an erroneous biological interpretations. This can be particularly problematic when monitoring the immune response during cancer progression or during immunotherapy (Miragaia et al., 2019).

On the other hand, the higher temperature during dissociation led to the activation in the expression of IEGs, which can also result in the misinterpretation of the results. Members of IEGs are often used as cancer related markers, for example the Fos gene is considered as a prognosis marker for tumour progression in ovarian carcinoma (Mahner et al., 2008). Cell populations within the dissociated tumour samples have also been previously identified based on their IEGs expression when using scRNA-Seq experiments (Freeman, Jung and Ogle, 2016; Puram et al., 2017; Crinier, A. et al., 2018). However, the majority of these studies provided no thorough verification of their results using an alternative method, and therefore it is possible that their conclusions may be affected by artificial induction of IEGs expression. We found only one similar study by Tirosh et al. (2016), which confirmed scRNA-Seq results using immunohistochemistry.

We tested the effect of different factors on IEGs and found that the main source of induced expression is the dissociation temperature (Figure 2-4). In our hands, the addition of ActD reduced IEGs activation. However the improvement compared to the low dissociation temperature was negligible (Figure 4) and only the combination of both approaches led to the complete inhibition of artificial IEGs expression. Another source of cell stress comes from centrifugation and we hypothesized that the higher centrifgual force will lead to a higher effect on the IEGs expression. In contrast to our expectations, we observed no changes in the IEGs expression dependent on the centrifugal force (Figure 3). We believe that additional factors, which include centrifugation at $4{ }^{\circ} \mathrm{C}$ and using a minimal acceleration and breaking of the centrifugal speed, reduced the stress response.

The centrifugal force is an important factor for cell viability too. Optimization is required especially when working with fragile and sensitive cells. On the other hand, smaller/lighter cells require higher centrifugal forces for their efficient capture (Moroz, 1984). We performed a literature search and found only one example where the optimization of centrifugal force was discussed (10x Genomics, 2017). Even though the effect of the centrifugal force during single-cell suspension preparation is considerable for its quality, it is usually performed without optimization and often the published information about centrifugation is missing in the Methods section (Patel et al., 2014; Chung et al., 2017; Winterhoff et al., 2017). Standard protocol recommends a centrifugal force of $300 \mathrm{~g}$ (Miltenyi Biotec, 2018), even though a recently published protocol used a centrifugal force up to 1500 g (Bykov, Kim and Zamarin, 2019). Nevertheless, the choice for the optimal force is relies on the compromise between viability, yield and the potential capturing of all the cell types.

We summarized the effects of the different factors on the quality of single-cell suspension in Table 1 and discussed the other potential factors and their expected impact in Table 2. We showed that optimization of the dissociation protocol is a complicated and laborious process and that there is no gold standard applicable for every tissue type and biological experiment. Improvement of single or multiple parameters can result in changes in other parameters and subsequently on the quality of singlecell suspension. Surprisingly using the same condition showed good reproducibility even though the samples were collected from tumour tissue, which is known for its large heterogeneity. 
bioRxiv preprint doi: https://doi.org/10.1101/824714; this version posted October 31, 2019. The copyright holder for this preprint (which was not certified by peer review) is the author/funder, who has granted bioRxiv a license to display the preprint in perpetuity. It is made available under aCC-BY-NC-ND 4.0 International license.

Table 1: Effects of the different tested factors used during single-cell suspension preparation that affects the quality of the singlecell suspension.

\begin{tabular}{|c|c|c|c|c|}
\hline & $\begin{array}{l}\text { Higher enzyme } \\
\text { concentration }\end{array}$ & $\begin{array}{c}\text { Higher } \\
\text { temperature }\end{array}$ & $\begin{array}{c}\text { Presence of the } \\
\text { inhibitor of gene } \\
\text { expression }\end{array}$ & $\begin{array}{c}\text { Higher } \\
\text { centrifugation } \\
\text { force } \\
\end{array}$ \\
\hline Positive effect & $\begin{array}{l}\text { Higher } \\
\text { dissociation } \\
\text { effectivity }\end{array}$ & $\begin{array}{l}\text { Higher } \\
\text { dissociation } \\
\text { effectivity }\end{array}$ & $\begin{array}{l}\text { Inhibition of the } \\
\text { changes of the } \\
\text { cell state. } \\
\text { Higher yield at } \\
37^{\circ} \mathrm{C}\end{array}$ & $\begin{array}{l}\text { Better capture of } \\
\text { all the cell types } \\
\text { Higher yield }\end{array}$ \\
\hline Negative effect & Lower yield & $\begin{array}{l}\text { Activation of } \\
\text { IEGs }\end{array}$ & Not observed & $\begin{array}{l}\text { Lower viability } \\
\text { Disruption of } \\
\text { fragile cells }\end{array}$ \\
\hline
\end{tabular}

Table 2: Potential effects of the other factors used during single-cell suspension preparation that may affect the quality of the single-cell suspension.

\begin{tabular}{|c|c|c|c|c|c|}
\hline & $\begin{array}{l}\text { Longer time of } \\
\text { dissociation }\end{array}$ & $\begin{array}{l}\text { Bigger pore size } \\
\text { of the filter }\end{array}$ & $\begin{array}{l}\text { Lysis of the } \\
\text { erythrocytes }\end{array}$ & Debris removal & $\begin{array}{l}\text { Dead cell } \\
\text { removal }\end{array}$ \\
\hline Positive effect & $\begin{array}{l}\text { Higher } \\
\text { dissociation } \\
\text { effectivity }\end{array}$ & Higher yield & $\begin{array}{l}\text { Removal of } \\
\text { erythrocytes, } \\
\text { which are not } \\
\text { interesting for } \\
\text { analysis and } \\
\text { interfere with } \\
\text { proper cell } \\
\text { viability } \\
\text { measurement }\end{array}$ & $\begin{array}{l}\text { Reduce } \\
\text { background. }\end{array}$ & $\begin{array}{l}\text { Higher cell } \\
\text { viability }\end{array}$ \\
\hline Negative effect & $\begin{array}{l}\text { More time for } \\
\text { cells to change } \\
\text { their state }\end{array}$ & $\begin{array}{l}\text { More dublets } \\
\text { Capillary clogging } \\
\text { during scRNA- } \\
\text { Seq library prep } \\
\text { in droplet based } \\
\text { instruments }\end{array}$ & $\begin{array}{l}\text { Method used for } \\
\text { the removal of } \\
\text { erythrocytes can } \\
\text { remove other } \\
\text { cell types as well } \\
\text { too. }\end{array}$ & $\begin{array}{l}\text { Centrifugation at } \\
\text { high force can } \\
\text { lead to } \\
\text { disruption of } \\
\text { fragile cells. } \\
\text { Protocol is based } \\
\text { on the density } \\
\text { and some cells } \\
\text { can be removed } \\
\text { together with } \\
\text { debris. }\end{array}$ & $\begin{array}{l}\text { Incubation at } \\
\text { room } \\
\text { temperature can } \\
\text { activate IEGs in } \\
\text { the cells }\end{array}$ \\
\hline
\end{tabular}




\section{METHODS}

\section{Ethics statement}

All animal studies were approved by the Czech Academy of Sciences and conducted in accordance with the Czech Council guidelines for the Care and Use of Animals in Research and Teaching.

\section{Tissue culture and mice}

The mouse 4T1 breast cancer cell line was obtained from the American Type Culture Collection (ATCC CRL2539) and was routinely cultivated in Roswell Park Memorial Institute (RPMI, Sigma) medium supplemented with $10 \%$ fetal bovine serum (Thermo Scientific) and $100 \mathrm{U} / \mathrm{mL}$ penicillin, $100 \mu \mathrm{g} / \mathrm{mL}$ streptomycin; in $5 \% \mathrm{CO}_{2}$ and $37^{\circ} \mathrm{C}$. When injected into Balb/c mice, 4T1 spontaneously produces highly metastatic tumour. Balb/c mice were subcutaneously injected with $1 \times 10^{6}$ of $4 \mathrm{~T} 1$ cells. After $20-25$ days, mice were sacrificed, and tumours were collected for further single cells preparation. Biological triplicate were used for every experiment.

\section{Single-cell suspension preparation}

Each tumour was cut into several pieces. One piece from each tumour was used for control RNA isolation of non-dissociated tissue. Remaining pieces of tumours were weighted (about $100 \mathrm{mg}$ ), minced by using polypropylene Pellet pestles for $1.5 \mathrm{~mL}$ tubes (Sigma, Z359947) in Eppendorf tubes and transferred into gentleMACS $\mathrm{C}$ tubes (Miltenyi Biotec) containing dissociation solution composed of $5 \mathrm{~mL}$ of RPMI media with tested enzymes according to Table 3. To inhibit the transcription during dissociation, we used $2 \mathrm{nM}$ ( 25 $\mu \mathrm{g} / \mathrm{ml}$ ) of Actinomycin D (ActD, Sigma A1410) in dissociation solution and $0.2 \mathrm{nM} \mathrm{ActD}(2,5 \mu \mathrm{g} / \mathrm{ml})$ in all following solutions. Tubes were mixed by using gentleMACS Dissociator (Miltenyi Biotec) program m_impTumor_02.01 (about $30 \mathrm{~s}$ ) placed in $4{ }^{\circ} \mathrm{C}$ and then on a rotating platform set at $20 \mathrm{rpm}$ for 20 minutes in $4^{\circ} \mathrm{C}$. This step was repeated 3 times for a total of 1 hour of dissociation. Dissociation at $37^{\circ} \mathrm{C}$ were performed using the gentleMACS OctoDissociator (Miltenyi Biotec) with heaters following the program parameters as outlined in Table 4. The total dissociation time was 1 hour.

Immediately after dissociation, all tubes were kept on ice while all solutions were pre-chilled in the ice. Cell suspension was filtered through a $30 \mu \mathrm{m}$ strainer (CellTrics, 04-004-2326) and from this point kept on ice. Cells were spun down $\left(5 \mathrm{~min}, 800 \mathrm{~g}, 2^{\circ} \mathrm{C}\right.$, minimal acceleration and break, Eppendorf $5810 \mathrm{R}$ with swingbucket rotor A-4-44). The medium was discarded and the cells were dissociated in $15 \mathrm{~mL}$ of ice cold ACK solution (0.15 M NH 4 Cl; $10 \mathrm{mM} \mathrm{KHCO}_{3} ; 0.1 \mathrm{mM}$ EDTA; $\mathrm{pH}$ 7.3) to remove erythrocytes. The cells suspension were immediately spun $\left(5 \mathrm{~min}, 800 \mathrm{~g}{ }^{\circ}, 2^{\circ} \mathrm{C}\right.$, minimal acceleration and break) and resuspended in $3.1 \mathrm{~mL}$ of ice-cold PBS without $\mathrm{Ca}^{2+}$ and $\mathrm{Mg}^{2+}$ (PBS -/-, Sigma, D8537). $900 \mu \mathrm{L}$ of ice-cold debris removal solution (Miltenyi Biotec, 130-109-398) was added to the solution, mixed, carefully overlaid with $4 \mathrm{~mL}$ of PBS -/and spun $\left(10 \mathrm{~min}, 3000 \mathrm{~g}, 2^{\circ} \mathrm{C}\right.$, full acceleration and brake). $5 \mathrm{~mL}$ of the upper phase solution was removed, the falcon tube was filled up with PBS -/-, mixed by inverting 3 times and spun $\left(5 \mathrm{~min}, 800 \mathrm{~g}^{\circ}, 2^{\circ} \mathrm{C}\right.$, minimal acceleration and break). The supernatant was removed and dead cells were removed using the Dead Cells Removal Kit according to the manufacturer's instruction (Miltenyi Biotec, 130-090-101). The collected effluent was spun $\left(5 \mathrm{~min}, 800 \mathrm{~g}^{\circ}, 2^{\circ} \mathrm{C}\right.$, minimal acceleration and break) and the cells resuspended in $110 \mu \mathrm{l}$ of PBS -/-. $10 \mu \mathrm{l}$ of the cells suspension were mixed with $10 \mu$ l of Trypan Blue (BioRad, \#1450021) and the number of the cells and viability were analysed using BioRad TC20 cell counter. The remaining $100 \mu \mathrm{l}$ of cells suspension were transferred to $1.5 \mathrm{ml}$ tube, immediately frozen using dry ice and stored in the $-80^{\circ} \mathrm{C}$ freezer.

- For testing of effect of different centrifugation force, centrifugation force between $300-3000$ g were used. 
Table 3 - list of tested enzyme conditions

\begin{tabular}{|c|c|c|c|c|c|}
\hline & Enzyme & $\begin{array}{l}\text { Enzyme } \\
\text { concentration }\end{array}$ & Medium & $\mathrm{CaCl}_{2}$ & DNAse \\
\hline A & Collagenase & $0.25 \mathrm{mg} / \mathrm{ml}$ & RPMI & $x$ & $50 \mu \mathrm{g} / \mathrm{ml}$ \\
\hline B & Collagenase & $0.25 \mathrm{mg} / \mathrm{ml}$ & RPMI & $10 \mathrm{mM}$ & $50 \mu \mathrm{g} / \mathrm{ml}$ \\
\hline C & Collagenase & $2.5 \mathrm{mg} / \mathrm{ml}$ & RPMI & $10 \mathrm{mM}$ & $50 \mu \mathrm{g} / \mathrm{ml}$ \\
\hline $\mathrm{D}$ & Collagenase & $10 \mathrm{mg} / \mathrm{ml}$ & RPMI & $10 \mathrm{mM}$ & $50 \mu \mathrm{g} / \mathrm{ml}$ \\
\hline$E$ & Protease & $0.25 \mathrm{mg} / \mathrm{ml}$ & RPMI & $10 \mathrm{mM}$ & $50 \mu \mathrm{g} / \mathrm{ml}$ \\
\hline $\mathrm{F}$ & Protease & $5 \mathrm{mg} / \mathrm{ml}$ & RPMI & $10 \mathrm{mM}$ & $50 \mu \mathrm{g} / \mathrm{ml}$ \\
\hline G & Protease & $10 \mathrm{mg} / \mathrm{ml}$ & RPMI & $10 \mathrm{mM}$ & $50 \mu \mathrm{g} / \mathrm{ml}$ \\
\hline $\mathrm{H}$ & Papain & $61.25 \mathrm{mg} / \mathrm{ml}$ & $\begin{array}{l}\text { PBS -/-, EDTA (0,5 mM), } \\
\text { L-Cystein (1 mM) }\end{array}$ & $x$ & $x$ \\
\hline I & $\begin{array}{l}\text { Papain } \\
\text { Collagenase }\end{array}$ & $\begin{array}{l}61.25 \mathrm{mg} / \mathrm{ml} \\
2.5 \mathrm{mg} / \mathrm{ml}\end{array}$ & $\begin{array}{l}\text { PBS -/-, EDTA }(0,5 \mathrm{mM}), \\
\text { L-Cystein }(1 \mathrm{mM})\end{array}$ & $x$ & $50 \mu \mathrm{g} / \mathrm{ml}$ \\
\hline J & Liberase & $0.25 \mathrm{mg} / \mathrm{ml}$ & RPMI & $x$ & $50 \mu \mathrm{g} / \mathrm{ml}$ \\
\hline K & $x$ & $\mathrm{x}$ & RPMI & $x$ & $50 \mu \mathrm{g} / \mathrm{ml}$ \\
\hline
\end{tabular}

Collagenase - Collagenase from Clostridium histolyticum, Sigma C7657, $250 \mathrm{mg} / \mathrm{ml}$ stock solution in PBS Protease - Protease from Bacillus licheniformis, Sigma P5380, $250 \mathrm{mg} / \mathrm{ml}$ stock solution in PBS -/Liberase - Liberase ${ }^{\mathrm{TM}}$ TL Research Grade, Roche $5401020001,2.5 \mathrm{mg} / \mathrm{ml}$ stock solution Papain - Papain solution, Merck L2223

DNase - DNAse I, Roche 11284932001, $10 \mathrm{mg} / \mathrm{ml}$ in nuclease free water (NFW, Invitrogen 10977-035) $\mathrm{CaCl}_{2}-1 \mathrm{M}$ stock solution in NFW

Table 4-gentleMACS Octo Dissociator program for dissociation at $37^{\circ} \mathrm{C}$

\begin{tabular}{|l|}
\hline 1. ramp $200 \mathrm{rpm}, 10^{\prime \prime}$ \\
\hline 2. loop $3 \mathrm{x}$ \\
\hline 3. spin $-200 \mathrm{rpm}, 1^{\prime \prime}$ \\
\hline 4. spin $200 \mathrm{rpm}, 10^{\prime \prime}$ \\
\hline 5. end loop \\
\hline 6. temp ON \\
\hline 7. loop $2 \mathrm{x}$ \\
\hline 8. spin $-30 \mathrm{rpm}, 30^{\prime}$ \\
\hline 9. spin $200 \mathrm{rpm}, 10^{\prime \prime}$ \\
\hline 10. end loop \\
\hline 11. temp OFF \\
\hline 12. end \\
\hline
\end{tabular}




\section{Gene expression analysis}

\section{RNA-isolation}

Tumour tissue were collected into $2 \mathrm{ml}$ tubes with prechilled steel beads (Qiagen Stainless Steel Beads, $5 \mathrm{~mm}, 69989$ ) and stored at $-80^{\circ} \mathrm{C}$ freezer. Cell suspension were collected into $1.5 \mathrm{ml}$ tubes, frozen on dry ice and stored at $-80^{\circ} \mathrm{C}$ freezer. Samples were mixed in $1 \mathrm{ml}$ of TRI Reagent (Sigma-Aldrich, T9424) with $2 \mu \mathrm{l}$ of GlycoBlue (AM9515, Invitrogen). Tissue were homogenized immediately using TissueLyser LT (Qiagen), for 10 minutes at $50 \mathrm{~Hz}$ and cell suspension were vortexed for 3 minutes. Total RNA was isolated following the manufacturer's manual. The RNA pellet was dissolved in $50 \mu \mathrm{l}$ of 1 xTE buffer (Invitrogen, 12090-015) and reprecipitated with addition of $50 \mu \mathrm{l}$ of $8 \mathrm{M} \mathrm{LiCl}$ (Sigma-Aldrich, L7026) at $-20^{\circ} \mathrm{C}$ freezer overnight. This solution were centrifuged for 30 minutes at $16000 \mathrm{~g}$. The supernatant were removed and RNA was washed twice with $1 \mathrm{ml}$ of $80 \%$ ethanol followed by centrifugation for 30 minutes. The final RNA pellet was diluted in $20 \mu$ l of 1xTE buffer (or $100 \mu \mathrm{l}$ for samples from non-dissociated tissue). The concentration of RNA from tissue were measured using Nanodrop 2000 (Thermo Scientific).

\section{$\underline{R T-q P C R}$}

The RNA from the tumour tissue were diluted to a final concentration of $5 \mathrm{ng} / \mu \mathrm{l}$ while the RNA from the cell suspension was used undiluted. The $5 \mu$ l of RNA were mixed with $0.5 \mu$ l RNA Spike I (TATAA, Biocenter), $2 \mu \mathrm{l}$ of TATAA GrandScript cDNA Synthesis Kit and $2.5 \mu \mathrm{l}$ of 1XTE Buffer. Reverse transcription was performed according to the manufacturer's protocol $\left(22^{\circ} \mathrm{C} 5 \mathrm{~min}\right.$, $42{ }^{\circ} \mathrm{C} 30 \mathrm{~min}, 85^{\circ} \mathrm{C} 5 \mathrm{~min}, 4^{\circ} \mathrm{C}$ ) and the synthesized CDNA was diluted 10 times in 1xTE buffer. $2 \mu \mathrm{l}$ of the final diluted $C D N A$ was added to the $\mathrm{QPCR}$ reaction $(2 x$ SYBRGreen mix, TATAA Biocenter, $400 \mathrm{nM}$ primers mix and Nuclease-free water to final volume $7 \mu \mathrm{l}$ ). Primers sequences are listed in the Table S1. The qPCR were run on BioRad C1000 Thermal cycler and protocol for qPCR was: 1 minute at $95^{\circ} \mathrm{C}$; 50 cycles of $95^{\circ} \mathrm{C}$ for 3 seconds, $60^{\circ} \mathrm{C}$ for 30 seconds and $72{ }^{\circ} \mathrm{C}$ for 10 seconds; followed by melting curve analysis.

\section{Data analysis and statistics}

Measured $C_{q}$ values for each gene were normalized to Actb $\left(\Delta C_{q}\right)$. Relative quantity for each sample was calculated according to formula:

$$
R Q_{i}=2^{\Delta C_{q, \text { non-dissociate }, i}-\Delta C_{q, i}}
$$

$R Q_{i}$ - Relative quantity of expression of gene of replicate $i$

$\Delta \mathrm{C}_{\mathrm{q}, \text { non-dissociated, } \mathrm{I}}-\Delta \mathrm{C}_{\mathrm{q}}$ for non-dissociated control tissue sample of replicate $i$

$\Delta \mathrm{C}_{\mathrm{q}, \mathrm{i}} \Delta \mathrm{C}_{\mathrm{q}}$ for dissociated sample of replicate $i$

The final $R Q$ is expressed as the geometric mean multiplied or divided by $\left({ }^{*} \div\right)$ geometric Standard deviation (geometric SD) (Kirkwood, 1979). The statistical significance was calculated from log2 transformed $\mathrm{RQ}_{i}$ values using GraphPad Prism 7 Twoway ANOVA with Dunnett's multiple comparisons test.

The cell viability is expressed as the arithmetic mean plus minus $( \pm)$ SD.

The yield of the live cells was calculated as number of live cells divided by weight of tumour tissue used for dissociation. The yield is expressed as arithmetic mean \pm SD.

\section{Scoring}

Six different parameters were scored to choose the best condition:

1. Cell viability.

2. Number of live cells obtained from one milligram of the tissue.

3. Expression of four different genes (Fos, Cldn4, Top2a, Vim)

For each measured parameter were calculated score from 0 to 10 to choose the best condition, where 0 is the best and 10 is the worst.

For viability -0 is $0 \%$ viability and 10 is $100 \%$ viability

For number of live cells - 0 is for 0 live cells and 10 is for 1500 or more live cells from $\mathrm{mg}$ of the tissue.

For gene expression - all numbers were $\log _{2}$ transformed and absolute values were calculated. Score 10 is for no changes between control tissue and dissociated sample $\left(\log _{2}(R Q)=0\right)$ and score 0 is for the highest change for tested gene. 


\section{Single-cell RNA Sequencing}

\section{Cell suspension preparation}

Balb/c mice were subcutaneously injected with $1 \times 10^{6}$ of $4 \mathrm{~T} 1$ cells. After 10 days, tumours were collected, weighted and processed according to the protocol mentioned above. A pool of 6 pieces of the tumour from different mice were used for each condition. In the final step, cells were resuspended in $100 \mu \mathrm{l}$ PBS-/with $0.04 \%$ BSA (AM2616, Invitrogen) without ActD and concentration of the cells was analysed using TC20 cell counter (BioRad). The suspension was spun ( $5 \mathrm{~min}$, $800 \mathrm{~g}, 2{ }^{\circ} \mathrm{C}$, minimal acceleration and break), supernatant removed and cells were resuspended to a final concentration of $2500 \mathrm{cell} / \mu \mathrm{l}$. The concentration and viability of the cells were measured two times and marked in the table (Table S2).

\section{Library preparation}

Two technical duplicates per condition were prepared (in total 8 samples). ScRNA-Seq libraries were prepared using SureCell WTA 3' Library Prep Kit for the ddSEQ System (Illumina/Bio-Rad) according to manufacturer's manual. Briefly, cells were individually partitioned into the droplets together with beads with barcodes and RT mix using ddSEQ Single-Cell Isolator (Bio-Rad). The cell lysis and RT took place in each droplet. Then, because cDNA:mRNA from each cells is barcoded, droplets could be disrupted and second strand were synthesized in bulk. After second strand synthesis, double stranded cDNA were analysed using Fragment Analyzer (AATI, HS NGS Fragment kit, DNF-474).

Double-stranded cDNA were tagmented using Nextera SureCell transposome. Final libraries were subsequently indexed during PCR amplification and purified. Before pooling of final libraries, the quality of the libraries were measured using a Fragment Analyzer (AATI, HS NGS Fragment kit, DNF-474). The pooled libraries were sequenced using NextSeq 500 instrument (Illumina) in HighOutput mode with setup Read1 70 cycles, Index 8 cycles, Read 28 cycles. Read 1 contains 0-5 bp long Phase Block, three 6 bp long cell barcodes (BC1-3) split with two linkers 15 bp long, cell barcodes are followed with ACG sequence, 8 bp long unique molecular identifiers (UMI), GAC sequence and several Ts. Read 2 contained the insert sequence in the same strand as the mRNA.

\section{$\underline{\text { Data analysis }}$}

On average $30 \mathrm{M}$ reads per sample were obtained. Count table per cell were generated using umi-tools ( $v$. 1.0.0) (Smith, Heger and Sudbery, 2017) following the manual with small modifications. At first, umi_tools whitelist was used to identify a list of correct cell barcodes with bc-pattern defined as regex (full command available in File S1) and set-cell-number to 3000. Next, umi_tools extract was used to copy cell barcode and umi sequence from read1 to the name of the read2. The whitelist generated from the previous step was used to filter reads with correct cell barcode with option for error correction of mismatches in it. Read 2 was then used alone for further downstream analysis. The low quality reads and adaptor sequences were removed using TrimmomaticSE (Bolger, Lohse and Usadel, 2014) with the parametres “ILLUMINACLIP:/mnt/d/Adapters/ddSeq_SureCell.fa:2 :30:10 LEADING:3 TRAILING:3 SLIDINGWINDOW:4:15 MINLEN:36". Then, reads were mapped to the mouse genome (GRCm38) using STAR (v. 2.7.1a) (Dobin et al., 2013) with the removal of reads which were mapped to more than one site. Reads were then assigned to the genes using featureCounts (v. 1.6.0) (Liao, Smyth and Shi, 2014) using the annotation genecode.vM8.gtf and parameter "-s 1" for definition of strand specificity of reads. Finally, the obtained BAM file was sorted and indexed using samtools (v. 1.7) (Li et al., 2009; Li, 2011) and the final table with information about counts of UMI per gene per cell were generated using umi_tools count with parameters "-per-gene and -wide-formatcell-counts". The full list of commands used for analysis is available as File $\mathbf{S 1 .}$

\section{Clustering}

The processing of data were made using $R$ ( $v$. 3.5.2). The raw count tables from all samples were first loaded into a Single Cell Experiment object. Genes that were not detected across all samples, were removed. $\mathrm{R}$ package DropletUtils (v 1.2.2) (Lun et al., 2019) was used to identify empty drops in the dataset, and only "cells" with more than 200, less than 5000 UMIs and FDR $\leq 0,05$ were processed in the next step. The Scater package (v 1.10.1) (McCarthy et al., 2017) was used to calculate the Quality control matrix, and features which were not detected in at least two cells were removed from the dataset. The data was then changed 
into a Seurat object and normalized (Seurat package $v$ 3.0.2) (Stuart et al., 2019; Butler et al., 2018). Cells from technical replicates were analysed as one condition. UMAP clustering (v 0.3.9) (Becht et al., 2018; McInnes et al., 2018) with PCA reduction were used to identify cell clusters. Two clusters, which were identified as cell debris were removed from analysis and the new subset of cells were reclustered again. In total 654 cells were analysed (average 164 cells per condition, min 88 cells, max 219 cells). The markers of cell clusters were identified using the function "FindConservedMarkers" and clusters of similar cell type were merged into one. The full list of commands used for analysis is available as File $\mathbf{S 1 .}$

\section{ACKNOWLEDGMENTS}

We thank Lukáš Valihrach for helpful discussion during discussion about experiments; Ravindra Naraine for grammar corrections. We thank to Genomics and
Bioinformatics Core Facility at Institute of Molecular Genetics of the Czech Academy of Sciences (RVO: 68378050) for borrowed Bio-Rad ddSEQ Single-Cell Isolator instrument. This work was supported by the Grant Agency of the Czech Republic GA17-24441S; Institutional support (RVO: 86652036 and BIOCEV CZ.1.05/1.1.00/02.0109).

\section{AUTHOR CONTRIBUTIONS}

P.A. performed RNA isolation, RT-qPCR experiments, single-cell library preparation and data analysis, wrote the manuscript and prepared all figures. P.A., S.L. performed tissue dissociation S.L., J.T. performed cell preparation and animal surgeries M.K., J.T., R.S. conceived and supervised the study. All authors reviewed the manuscript.

\section{DECLARATION OF INTERESETS}

The authors declare no competing of interests. 


\section{SUPPLEMENTAL MATERIALS}

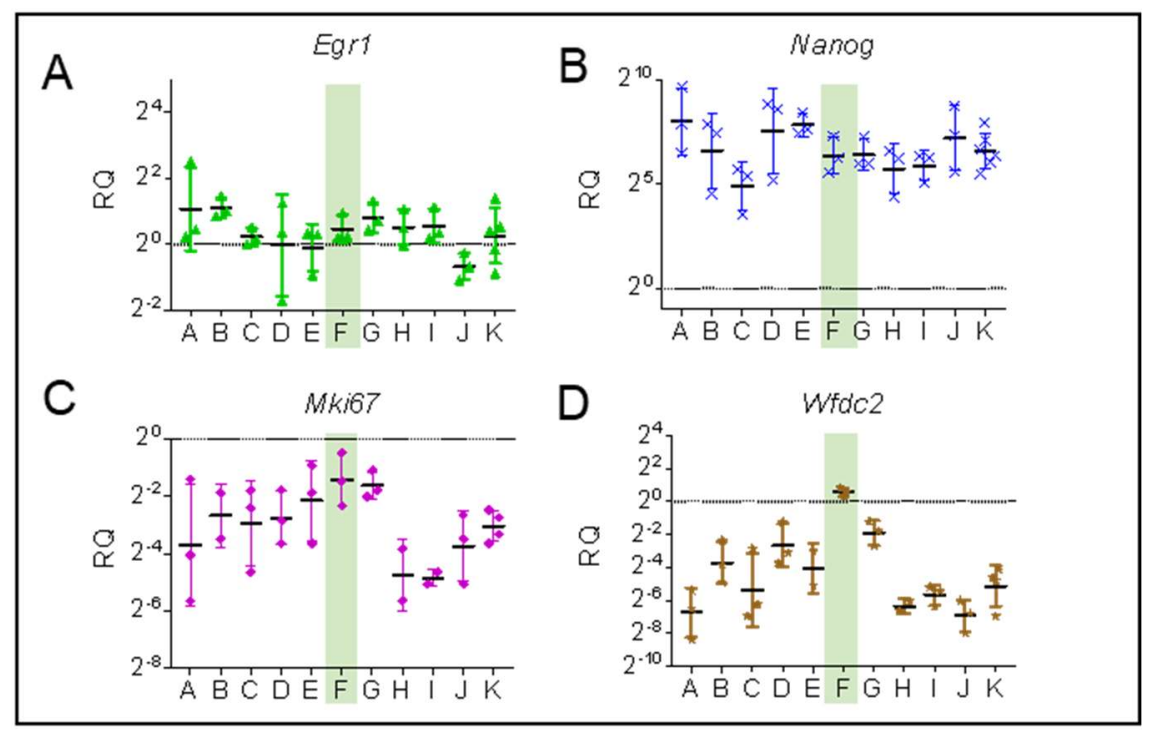

Figure S1: The effect of various enzymes and their combination on the dissociation of the tumour tissue.

The effects of enzymes and their concentrations were assessed by comparing the relative expression of some additional marker genes after dissociation, normalized to the non-dissociated tissue pieces. The black line represents the expression in non-dissociated tumour tissue. (geometric mean with geometric SD) (A) Egr1 - a member of IEGs, (B) Nanog - a marker of tumour endothelial stem cells, (C) Mki67 - a marker of proliferating cells, (D) Wfdc2 - a marker of tumour epithelial cells. The optimal dissociation condition marked in green.

A

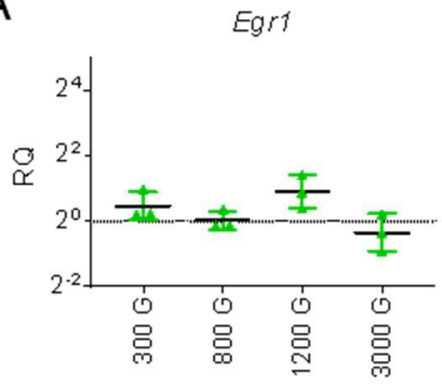

C

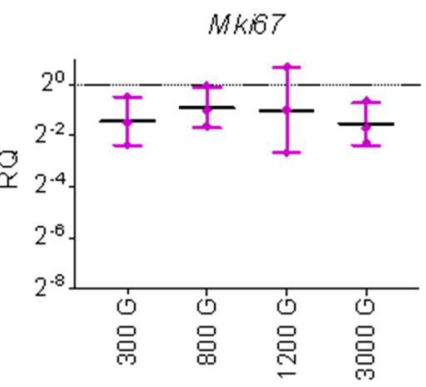

B

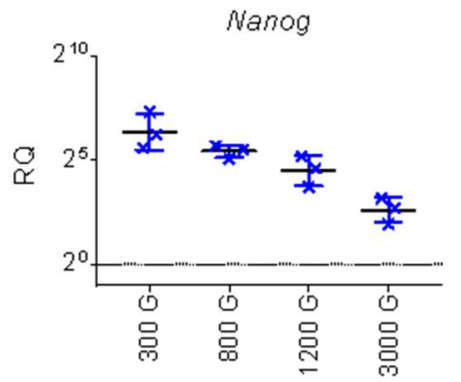

D

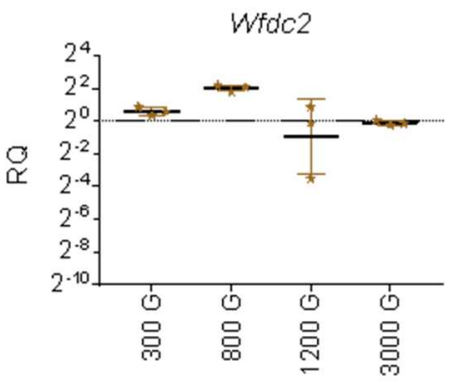

Figure S2: The effect of centrifugation force after tumour tissue dissociation on cellular viability and gene expression.

Relative expression of additional marker genes after dissociation normalized to non-dissociated tissue piece comparing the effects of different centrifugation forces. The black line represents the expression in non-dissociated tumour tissue. (geometric mean with geometric SD) (A) Egr1 - a member of IEGs, (B) Nanog - a marker of tumour endothelial stem cells, (C) Mki67 - a marker of proliferating cells, (D) Wfdc2 - a marker of tumour epithelial cells. 
bioRxiv preprint doi: https://doi.org/10.1101/824714; this version posted October 31, 2019. The copyright holder for this preprint (which was not certified by peer review) is the author/funder, who has granted bioRxiv a license to display the preprint in perpetuity. It is made available under aCC-BY-NC-ND 4.0 International license.

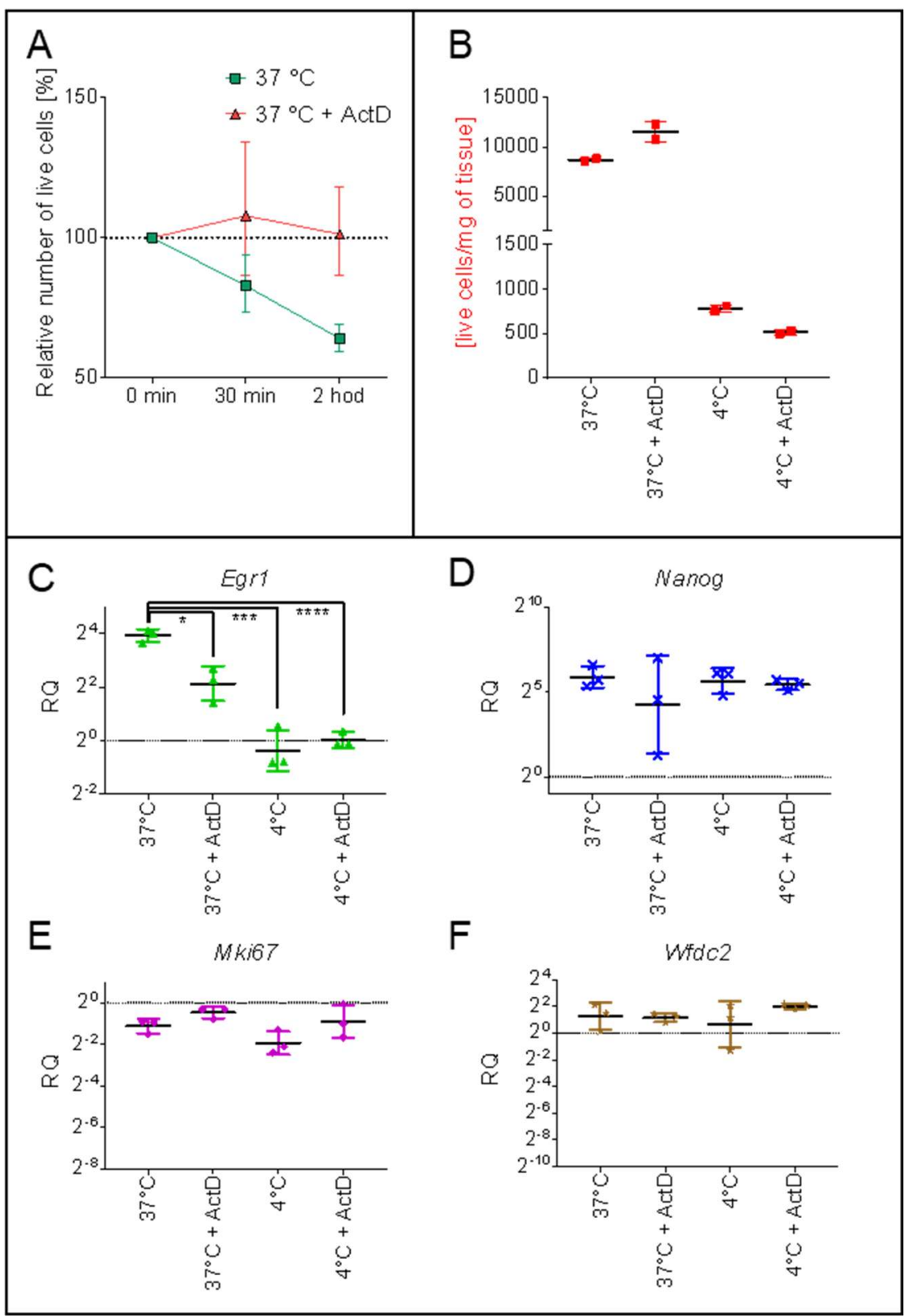

Figure S3: The effect of temperature and ActD on gene expression in dissociated tumour tissue.

(A) Changes in number of live cells during incubation of cell suspension with or without ActD. Tumour tissue were dissociated at $37^{\circ} \mathrm{C}$ for 1 hour with or without ActD. After that, cell suspension were washed and incubated at $37^{\circ} \mathrm{C}$ in RPMI medium without enzyme with or without ActD. Number of the live cells were counted and compared with number of the live cells at the beginning of the incubation. (B) The yield of the live cells after dissociation of the tumour 10 days after injection. (C-F) Relative expression of additional marker genes after dissociation normalized to non-dissociated tissue piece comparing the effects of dissociation temperature and presence of ActD. The black line represents the expression in non-dissociated tumour tissue. (geometric mean with geometric SD) (C) Egr1 - a member of IEGs, (D) Nanog - a marker of tumour endothelial stem cells, (E) Mki67 - a marker of proliferating cells, (F) Wfdc2 - a marker of tumour epithelial cells. The optimal dissociation condition marked in green.

Dunnett's multiple comparisons test, $* * * *-p<0,0001, * *-p<0,01, *-p<0,05$, n.s. $-p>0,05$ 
bioRxiv preprint doi: https://doi.org/10.1101/824714; this version posted October 31, 2019. The copyright holder for this preprint (which was not certified by peer review) is the author/funder, who has granted bioRxiv a license to display the preprint in perpetuity. It is made available under aCC-BY-NC-ND 4.0 International license.

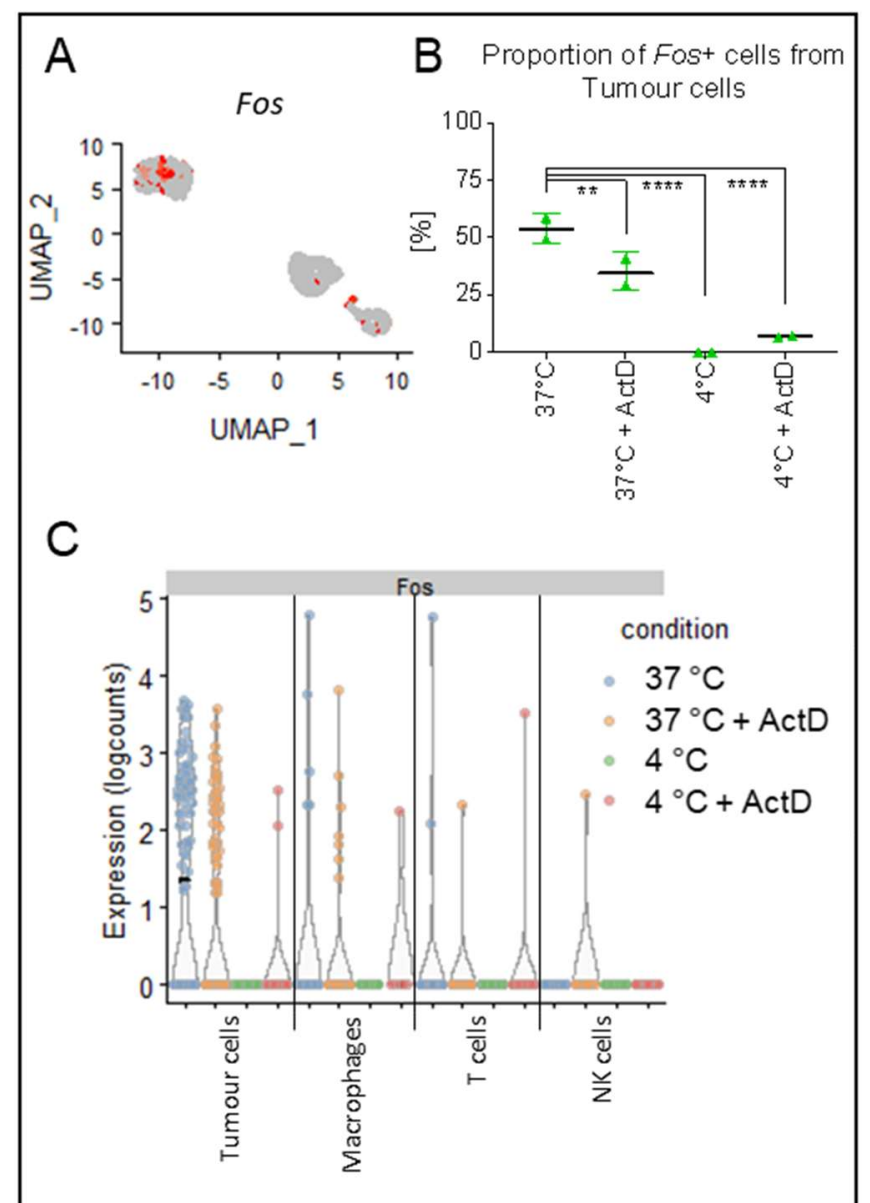

Figure S4: Identification of level of expression of Fos in tumour populations after different dissociation condition.

(A) UMAP plot with marked individual cells positive for expression of Fos. (B) Proportion of Fos + cells from tumour cell type (mean \pm SD). (C) Level of expression of Fos in individual cells of different cell types.

Dunnett's multiple comparisons test, $* * * *-p<.0001, * * *-p<.001, * *-p<.01$ 
Table S1: List of primers used for RT-qPCR

\begin{tabular}{|c|c|c|}
\hline Fos & Forward primer & GGTGAAGACCGTGTCAGGAG \\
\hline NM_010234.3 & Reverse primer & AGCCATCTTATTCCGTTCCCTT \\
\hline Cldn4 & Forward primer & TGATTATGGTGCCCGTGTCC \\
\hline NM_009903.2 & Reverse primer & CCAGCCGACGTAAAGCGA \\
\hline Top2A & Forward primer & CCTCCGGCAACGAATAGAGA \\
\hline NM_011623.2 & Reverse primer & TTGACAGGCTTAAACGGCAA \\
\hline Egr1 & Forward primer & CGAACAACCCTATGAGCACC \\
\hline NM_007913.5 & Reverse primer & GGGATAACTCGTCTCCACCA \\
\hline Mki67 & Forward primer & CTCTGGCCTACCTGGTCTTA \\
\hline NM_001081117.2 & Reverse primer & TTCCTCTTGGTTGGCGTTTC \\
\hline$W f d c 2$ & Forward primer & TTACGGACTGTGTGTTGGAGT \\
\hline NM_026323.2 & Reverse primer & CTGAGAGTTTAGTATCTGTCCCTGA \\
\hline Fcgr3 & Forward primer & AGTGGGGACTACTACTGCAAA \\
\hline NM_010188.5 & Reverse primer & CAGACTAGAGAGATGGAGGATGT \\
\hline $\mathrm{Ccl5}$ & Forward primer & TCAAGGAGTATTTCTACACCAGCA \\
\hline NM_013653.3 & Reverse primer & СССТСТАТССТАGСТСАТСТССА \\
\hline Thy1 & Forward primer & TCCAAGTCGGAACTCTTGGC \\
\hline NM_009382.3 & Reverse primer & AGGCGAAGGTTTTGGTTCAC \\
\hline Actb & Forward primer & GCTCCTAGCACCATGAAGAT \\
\hline NM_007393.5 & Reverse primer & TAAAACGCAGCTCAGTAACAG \\
\hline Vim & Forward primer & TGCCAACCTTTTCTTCCCTG \\
\hline NM_011701 & Reverse primer & TCTCTGGTCTCAACCGTCTT \\
\hline Nanog & Forward primer & GCTTACAAGGGTCTGCTACT \\
\hline NM_028016 & Reverse primer & GAGCTTTTGTTTGGGACTGGT \\
\hline
\end{tabular}


Table S2: Lab tracking chart for scRNA-Seq library preparation

\begin{tabular}{|c|c|c|c|c|c|c|c|c|}
\hline \multirow{2}{*}{ Step: Cell preparation } & \multicolumn{4}{|c|}{ Cell samples } & \multicolumn{4}{|c|}{ Cell samples } \\
\hline & Sample 1 & Sample 2 & Sample 3 & Sample 4 & Sample 1 & Sample 2 & Sample 3 & Sample 4 \\
\hline Sample number & 1 & 2 & 3 & 4 & 1 & 2 & 3 & 4 \\
\hline Cell Viability (\%) & $89 \%$ & $87 \%$ & $81 \%$ & $77 \%$ & $89 \%$ & $87 \%$ & $81 \%$ & $77 \%$ \\
\hline Cell concentration (cell/ $\mu \mathrm{l})$ & 2510 & 3100 & 2520 & 2040 & 2510 & 3100 & 2520 & 2040 \\
\hline $\begin{array}{l}\text { Single-cell suspension } \\
\text { (visually confirmed - Yes/No) }\end{array}$ & Yes & Yes & Yes & Yes & Yes & Yes & Yes & Yes \\
\hline
\end{tabular}

\begin{tabular}{|c|c|c|c|c|c|c|c|c|c|c|c|c|c|c|c|c|}
\hline \multirow[t]{2}{*}{ Step: Cell preparation } & \multicolumn{8}{|c|}{ Cartridge ports } & \multicolumn{8}{|c|}{ Cartridge ports } \\
\hline & $1 \mathrm{~A}$ & $1 \mathrm{~B}$ & $1 C$ & $1 \mathrm{D}$ & $1 \mathrm{E}$ & $1 \mathrm{~F}$ & $1 \mathrm{G}$ & $1 \mathrm{H}$ & $2 A$ & $2 B$ & $2 C$ & $2 \mathrm{D}$ & $2 \mathrm{E}$ & $2 \mathrm{~F}$ & $2 G$ & $2 \mathrm{H}$ \\
\hline $\begin{array}{l}\text { Visible cloudy droplets observed in } \\
\text { output wells after single-cell isolation } \\
\text { (Yes/No) }\end{array}$ & Yes & Yes & Yes & Yes & Yes & Yes & Yes & Yes & Yes & Yes & Yes & Yes & Yes & Yes & Yes & Yes \\
\hline $\begin{array}{l}\text { Both oil and aqueous layers visible in } \\
\text { PCR plate (Yes/No) }\end{array}$ & Yes & Yes & Yes & Yes & Yes & Yes & Yes & Yes & Yes & Yes & Yes & Yes & Yes & Yes & Yes & Yes \\
\hline
\end{tabular}

\begin{tabular}{|c|c|c|c|c|c|c|c|c|}
\hline Step: After cDNA syntehis & & & ary & & & cDI & ary & \\
\hline & Sample 1 & Sample 2 & Sample 3 & Sample 4 & Sample 1 & Sample 2 & Sample 3 & Sample 4 \\
\hline Sample number & 1 & 2 & 3 & 4 & 1 & 2 & 3 & 4 \\
\hline Average cDNA fragment size (bp) & 2331 & 2232 & 2468 & 3890 & 2257 & 1865 & 2684 & 2691 \\
\hline cDNA yield (ng) & 1,028 & 1,127 & 0,963 & 0,488 & 1,085 & 1,386 & 0,869 & 0,78 \\
\hline
\end{tabular}

\begin{tabular}{|c|c|c|c|c|c|c|c|c|}
\hline \multirow[t]{2}{*}{ Step: Final library QC } & \multicolumn{4}{|c|}{ Final library samples } & \multicolumn{4}{|c|}{ Final library samples } \\
\hline & Sample 1 & Sample 2 & Sample 3 & Sample 4 & Sample 1 & Sample 2 & Sample 3 & Sample 4 \\
\hline Sample number & 1 & 2 & 3 & 4 & 1 & 2 & 3 & 4 \\
\hline Average cDNA fragment size (bp) & 333 & 358 & 306 & 294 & 343 & 354 & 325 & 302 \\
\hline Total library yield (nM) & 18,8 & 27,1 & 12,6 & 10,6 & 12,9 & 16,8 & 11,9 & 12 \\
\hline
\end{tabular}




\section{REFERENCES}

10x Genomics (2017) Removal of Dead Cells from Single Cell Suspensions for Single Cell RNA Sequencing, 29 June, [Online], Available:

https://support.10xgenomics.com/permalink/LSYZWE H6OAESkEYUECWuC [29 October 2019].

10x Genomics (2017) Single Cell Protocols - Cell Preparation Guide, 29 June, [Online], Available: https://support.10xgenomics.com/permalink/g4m3ltP bhYqK6eSSyUASW [29 October 2019].

10x Genomics (2018) Tumor Dissociation for Single Cell RNA Sequencing, 15 February, [Online], Available: https://support.10xgenomics.com/permalink/5i68Sug vNC2ISI4oaUOMYO [10 October 2019].

Abaffy, P., Tomankova, S., Naraine, R., Kubista, M. and Sindelka, R. (in press) 'The role of nitric oxide during embryonic wound healing.', BMC Genomics.

Adam, M., Potter, A.S. and Potter, S.S. (2017)

'Psychrophilic proteases dramatically reduce singlecell RNA-seq artifacts: a molecular atlas of kidney development', Development, vol. 144, no. 19, pp. 3625-3632.

Andor, N., Lau, B.T., Catalanotti, C., Kumar, V., Sathe, A., Belhocine, K., Wheeler, T.D., Price, A.D., Song, M., Stafford, D., Bent, Z., DeMare, L., Hepler, L., Jett, S., Kengli Lin, B., Maheshwari, S., Makarewicz, A.J., Rahimi, M., Sawhney, S.S., Sauzade, M. et al. (2018) 'Joint single cell DNA-Seq and RNA-Seq of gastric cancer reveals subclonal signatures of genomic instability and gene expression'.

Becht, E., McInnes, L., Healy, J., Dutertre, C.A., Kwok, I.W.H., Ng, L.G., Ginhoux, F. and Newell, E.W. (2018) 'Dimensionality reduction for visualizing single-cell data using UMAP', Nat Biotechnol.

Bolger, A.M., Lohse, M. and Usadel, B. (2014) 'Trimmomatic: a flexible trimmer for Illumina sequence data', Bioinformatics, vol. 30 , no. 15 , pp. 2114-20.
Butler, A., Hoffman, P., Smibert, P., Papalexi, E. and Satija, R. (2018) 'Integrating single-cell transcriptomic data across different conditions, technologies, and species', Nat Biotechnol, vol. 36, no. 5, pp. 411-420.

Bykov, Y., Kim, S.H. and Zamarin, D. (2019)

'Preparation of single cells from tumors for single-cell RNA sequencing', Methods Enzymol.

Cortes, C.L., Veiga, S.R., Almacellas, E., HernandezLosa, J., Ferreres, J.C., Kozma, S.C., Ambrosio, S., Thomas, G. and Tauler, A. (2016) 'Effect of low doses of actinomycin D on neuroblastoma cell lines', $\mathrm{Mol}$ Cancer, vol. 15, p. 1.

Crinier, A., Milpied, P., Escaliere, B., Piperoglou, C., Galluso, J., Balsamo, A., Spinelli, L., Cervera-Marzal, I., Ebbo, M., Girard-Madoux, M., Jaeger, S., Bollon, E., Hamed, S., Hardwigsen, J., Ugolini, S., Vely, F., NarniMancinelli, E. and Vivier, E. (2018) 'High-Dimensional Single-Cell Analysis Identifies Organ-Specific Signatures and Conserved NK Cell Subsets in Humans and Mice', Immunity, vol. 49, no. 5, pp. 971-986 e5.

Ding, Y., Colozza, G., Zhang, K., Moriyama, Y., Ploper, D., Sosa, E.A., Benitez, M.D.J. and De Robertis, E.M. (2017) 'Genome-wide analysis of dorsal and ventral transcriptomes of the Xenopus laevis gastrula', Dev Biol, vol. 426, no. 2, pp. 176-187.

Dobin, A., Davis, C.A., Schlesinger, F., Drenkow, J., Zaleski, C., Jha, S., Batut, P., Chaisson, M. and Gingeras, T.R. (2013) 'STAR: ultrafast universal RNAseq aligner', Bioinformatics, vol. 29, no. 1, pp. 15-21.

Freeman, B.T., Jung, J.P. and Ogle, B.M. (2016) 'Singlecell RNA-seq reveals activation of unique gene groups as a consequence of stem cell-parenchymal cell fusion', Sci Rep, vol. 6, p. 23270.

Gao, R., Kim, C., Sei, E., Foukakis, T., Crosetto, N., Chan, L. K., Srinivasan, M., Zhang, H., Meric-Bernstam, F. and Navin, N. (2017) 'Nanogrid single-nucleus RNA sequencing reveals phenotypic diversity in breast cancer', Nat Commun, vol. 8, no. 1, p. 228.

Grindberg, R. V., Yee-Greenbaum, J. L., McConnell, M. J., Novotny, M., O'Shaughnessy, A. L., Lambert, G. M., 
Arauzo-Bravo, M. J., Lee, J., Fishman, M., Robbins, G. E., Lin, X., Venepally, P., Badger, J. H., Galbraith, D. W., Gage, F. H. and Lasken, R. S. (2013) 'RNA-sequencing from single nuclei', Proc Natl Acad Sci U S A, vol. 110, no. 49 , pp. 19802-7.

Grose, R., Harris, B.S., Cooper, L., Topilko, P. and Martin, P. (2002) 'Immediate early genes krox-24 and krox-20 are rapidly up-regulated after wounding in the embryonic and adult mouse', Dev Dyn, vol. 223, no. 3, pp. 371-8.

Guo, F., Li, L., Li, J., Wu, X., Hu, B., Zhu, P., Wen, L. and Tang, F. (2017) 'Single-cell multi-omics sequencing of mouse early embryos and embryonic stem cells', Cell Res, vol. 27, no. 8, pp. 967-988.

Habib, N., Avraham-Davidi, I., Basu, A., Burks, T., Shekhar, K., Hofree, M., Choudhury, S.R., Aguet, F., Gelfand, E., Ardlie, K., Weitz, D.A., Rozenblatt-Rosen, O., Zhang, F. and Regev, A. (2017) 'Massively parallel single-nucleus RNA-seq with DroNc-seq', Nat Methods, vol. 14, no. 10, pp. 955-958.

Habib, N., Li, Y., Heidenreich, M., Swiech, L., AvrahamDavidi, I., Trombetta, J.J., Hession, C., Zhang, F. and Regev, A. (2016) 'Div-Seq: Single-nucleus RNA-Seq reveals dynamics of rare adult newborn neurons', Science, vol. 353, no. 6302, pp. 925-8.

Hou, Y., Guo, H., Cao, C., Li, X., Hu, B., Zhu, P., Wu, X., Wen, L., Tang, F., Huang, Y. and Peng, J. (2016) 'Singlecell triple omics sequencing reveals genetic, epigenetic, and transcriptomic heterogeneity in hepatocellular carcinomas', Cell Res, vol. 26, no. 3, pp. 304-19.

Cheung, P., Vallania, F., Warsinske, H.C., Donato, M., Schaffert, S., Chang, S.E., Dvorak, M., Dekker, C.L., Davis, M.M., Utz, P.J., Khatri, P. and Kuo, A.J. (2018) 'Single-Cell Chromatin Modification Profiling Reveals Increased Epigenetic Variations with Aging', Cell, vol. 173 , no. 6 , pp. $1385-1397$ e14.

Chung, W., Eum, H.H., Lee, H.O., Lee, K.M., Lee, H.B., Kim, K.T., Ryu, H.S., Kim, S., Lee, J.E., Park, Y.H., Kan, Z., Han, W. and Park, W.Y. (2017) 'Single-cell RNA-seq enables comprehensive tumour and immune cell profiling in primary breast cancer', Nat Commun, vol. 8, p. 15081.

Illumina and Bio-Rad (2017) Illumina Bio-Rad SureCell WTA 3' Library, June, [Online], Available: https://support.illumina.com/content/dam/illuminasupport/documents/documentation/chemistry docu mentation/surecell/surecell-wta3-library-prepreference-guide-1000000021452-01.pdf [29 October 2019].

Ishida, T., Nakajima, T., Kudo, A. and Kawakami, A. (2010) 'Phosphorylation of Junb family proteins by the Jun $\mathrm{N}$-terminal kinase supports tissue regeneration in zebrafish', Dev Biol, vol. 340, no. 2, pp. 468-79.

Joshi, S. and Satyanarayana, T. (2013) 'Biotechnology of cold-active proteases', Biology (Basel), vol. 2, no. 2, pp. 755-83.

Kirkwood, T.B.L. (1979) 'Geometric Means and Measures of Dispersion', Biometrics, vol. 35, no. 4, pp. 908-9.

Krishnaswami, S. R., Grindberg, R. V., Novotny, M., Venepally, P., Lacar, B., Bhutani, K., Linker, S. B., Pham, S., Erwin, J. A., Miller, J. A., Hodge, R., McCarthy, J. K., Kelder, M., McCorrison, J., Aevermann, B. D., Fuertes, F. D., Scheuermann, R. H., Lee, J., Lein, E. S., Schork, N. et al. (2016) 'Using single nuclei for RNA-seq to capture the transcriptome of postmortem neurons', Nat Protoc, vol. 11, no. 3, pp. 499-524.

Lacar, B., Linker, S. B., Jaeger, B. N., Krishnaswami, S. R., Barron, J. J., Kelder, M. J. E., Parylak, S. L., Paquola, A. C. M., Venepally, P., Novotny, M., O'Connor, C., Fitzpatrick, C., Erwin, J. A., Hsu, J. Y., Husband, D., McConnell, M. J., Lasken, R. and Gage, F. H. (2016) 'Nuclear RNA-seq of single neurons reveals molecular signatures of activation', Nat Commun, vol. 7, p. 11022.

Lawson, D.A., Kessenbrock, K., Davis, R.T., Pervolarakis, N. and Werb, Z. (2018) 'Tumour heterogeneity and metastasis at single-cell 
resolution', Nat Cell Biol, vol. 20, no. 12, pp. 13491360.

Li, H. (2011) 'A statistical framework for SNP calling, mutation discovery, association mapping and population genetical parameter estimation from sequencing data', Bioinformatics, vol. 27, no. 21, pp. 2987-93.

Liao, Y., Smyth, G.K. and Shi, W. (2014)

'featureCounts: an efficient general purpose program for assigning sequence reads to genomic features', Bioinformatics, vol. 30, no. 7, pp. 923-30.

Li, H., Handsaker, B., Handsaker, B., Fennell, T., Ruan, J., Homer, N., Marth, G., Abecasis, G., Durbin, R. and Subgroup, 1.G.P.D.P. (2009) 'The Sequence Alignment/Map format and SAMtools', Bioinformatics, vol. 25 , no. 16 , pp. 2078-9.

Lun, A.T.L., Riesenfeld, S., Andrews, T., Dao, T.P., Gomes, T., participants in the 1st Human Cell Atlas, J. and Marioni, J.C. (2019) 'EmptyDrops: distinguishing cells from empty droplets in droplet-based single-cell RNA sequencing data', Genome Biol, vol. 20, no. 1, p. 63.

Mahner, S., Baasch, C., Schwarz, J., Hein, S., Wolber, L., Janicke, F. and Milde-Langosch, K. (2008) 'C-Fos expression is a molecular predictor of progression and survival in epithelial ovarian carcinoma', Br J Cancer, vol. 99, no. 8, pp. 1269-75.

Machado, L., Esteves de Lima, J., Fabre, O., Proux, C., Legendre, R., Szegedi, A., Varet, H., Ingerslev, L.R., Barres, R., Relaix, F. and Mourikis, P. (2017) 'In Situ Fixation Redefines Quiescence and Early Activation of Skeletal Muscle Stem Cells', Cell Rep, vol. 21, no. 7, pp. 1982-1993.

McCarthy, D., Campbell, K., Lun, A. and Willis, Q. (2017) 'Scater: pre-processing, quality control, normalisation and visualisation of single-cell RNA-seq data in R', Bioinformatics, vol. 33, no. 8, pp. 1179-86.

McInnes, L., Healy, J., Saul, N. and Großberger, L. (2018) 'UMAP: Uniform Manifold Approximation and Projection', J Open Source Softw, vol. 3, no. 29, p. 861.
Miltenyi Biotec (2018) Tumor Dissociation Kit, mouse, [Online], Available:

https://www.miltenyibiotec.com/ Resources/Persiste nt/d141d24cf5cd337a758becdb51e5696c2b9fe692/D S Tumor\%20Dissociation\%20Kit m.pdf [29 October 2019].

Miragaia, R.J., Gomes, T., Chomka, A., Jardine, L., Riedel, A., Hegazy, A.N., Whibley, N., Tucci, A., Chen, X., Lindeman, I., Emerton, G., Krausgruber, T., Shields, J., Haniffa, M., Powrie, F. and Teichmann, S.A. (2019) 'Single-Cell Transcriptomics of Regulatory T Cells Reveals Trajectories of Tissue Adaptation', Immunity, vol. 50, no. 2, pp. 493-504 e7.

Moroz, P.E. (1984) 'The cell in the field of gravity and the centrifugal field', J Theor Biol, vol. 107, no. 2, pp. 303-20.

Patel, A.P., Tirosh, I., Trombetta, J.J., Shalek, A.K., Gillespie, S.M., Wakimoto, H., Cahill, D.P., Nahed, B.V., Curry, W.T., Martuza, R.L., Louis, D.N., RozenblattRosen, O., Suva, M.L., Regev, A. and Bernstein, B.E. (2014) 'Single-cell RNA-seq highlights intratumoral heterogeneity in primary glioblastoma', Science, vol. 344 , no. 6190 , pp. $1396-401$.

Potter, A.S. and Potter, S.S. (2019) 'Dissociation of Tissues for Single-Cell Analysis.', Methods Mol Biol, vol. 1926, pp. 55-62.

Pozhitkov, A.E., Neme, R., Domazet-Loso, T., Leroux, B.G., Soni, S., Tautz, D. and Noble, P.A. (2017) 'Tracing the dynamics of gene transcripts after organismal death', Open Biol, vol. 7, no. 1.

Puram, S.V., Tirosh, I., Parikh, A.S., Patel, A.P., Yizhak, K., Gillespie, S., Rodman, C., Luo, C.L., Mroz, E.A., Emerick, K.S., Deschler, D.G., Varvares, M.A., Mylvaganam, R., Rozenblatt-Rosen, O., Rocco, J.W., Faquin, W.C., Lin, D.T., Regev, A. and Bernstein, B. E. (2017) 'Single-Cell Transcriptomic Analysis of Primary and Metastatic Tumor Ecosystems in Head and Neck Cancer', Cell, vol. 171, no. 7, pp. 1611-1624 e24.

Schelker, M., Feau, S., Du, J., Ranu, N., Klipp, E., MacBeath, G., Schoeberl, B. and Raue, A. (2017) 
'Estimation of immune cell content in tumour tissue using single-cell RNA-seq data', Nat Commun, vol. 8, no. 1, p. 2032.

Smith, T., Heger, A. and Sudbery, I. (2017) 'UMI-tools: modeling sequencing errors in Unique Molecular Identifiers to improve quantification accuracy', Genome Res, vol. 27, no. 3, pp. 491-499.

Stuart, T., Butler, A., Hoffman, P., Hafemeister, C., Papalexi, E., Mauck, W.M..3., Hao, Y., Stoeckius, M., Smibert, P. and Satija, R. (2019) 'Comprehensive Integration of Single-Cell Data', Cell, vol. 177, no. 7, pp. 1888-1902 e21.

Tang, F., Barbacioru, C., Wang, Y., Nordman, E., Lee, C., Xu, N., Wang, X., Bodeau, J., Tuch, B.B., Siddiqui, A., Lao, K. and Surani, M.A. (2009) 'mRNA-Seq wholetranscriptome analysis of a single cell', Nat Methods, vol. 6 , no. 5 , pp. 377-82.

Tirosh, I., Izar, B., Prakadan, S. M., Wadsworth, M. H., 2nd, Treacy, D., Trombetta, J. J., Rotem, A., Rodman, C., Lian, C., Murphy, G., Fallahi-Sichani, M., DuttonRegester, K., Lin, J. R., Cohen, O., Shah, P., Lu, D., Genshaft, A. S., Hughes, T. K., Ziegler, C. G., Kazer, S. W. et al. (2016) 'Dissecting the multicellular ecosystem of metastatic melanoma by single-cell RNA-seq', Science, vol. 352, no. 6282, pp. 189-96.

Toyokawa, Y., Takahara, H., Reungsang, A., Fukuta, M., Hachimine, Y., Tachibana, S. and Yasuda, M. (2010) 'Purification and characterization of a halotolerant serine proteinase from thermotolerant Bacillus licheniformis RKK-04 isolated from Thai fish sauce', Appl Microbiol Biotechnol, vol. 86, no. 6, pp. 1867-75.

van den Brink, S.C., Sage, F., Vertesy, A., Spanjaard, B., Peterson-Maduro, J., Baron, C.S., Robin, C. and van Oudenaarden, A. (2017) 'Single-cell sequencing reveals dissociation-induced gene expression in tissue subpopulations', Nat Methods, vol. 14, no. 10, pp. 935-936.
Vieira Braga, F.A. and Miragaia, R.J. (2019) 'Tissue Handling and Dissociation for Single-Cell RNA-Seq', Methods Mol Biol, vol. 1979, pp. 9-21.

Winterhoff, B.J., Maile, M., Mitra, A.K., Sebe, A., Bazzaro, M., Geller, M.A., Abrahante, J.E., Klein, M., Hellweg, R., Mullany, S.A., Beckman, K., Daniel, J. and Starr, T.K. (2017) 'Single cell sequencing reveals heterogeneity within ovarian cancer epithelium and cancer associated stromal cells', Gynecol Oncol, vol. 144 , no. 3, pp. 598-606.

Wu, H., Kirita, Y., Donnelly, E.L. and Humphreys, B.D. (2019) 'Advantages of Single-Nucleus over Single-Cell RNA Sequencing of Adult Kidney: Rare Cell Types and Novel Cell States Revealed in Fibrosis', J Am Soc Nephrol, vol. 30, no. 1, pp. 23-32.

Wu, Y.E., Pan, L., Zuo, Y., Li, X. and Hong, W. (2017) 'Detecting Activated Cell Populations Using Single-Cell RNA-Seq', Neuron, vol. 96, no. 2, pp. 313-329 e6.

Yu, X., Chen, Y.A., Conejo-Garcia, J.R., Chung, C.H. and Wang, X. (2019) 'Estimation of immune cell content in tumor using single-cell RNA-seq reference data', BMC Cancer, vol. 19, no. 1, p. 715. 